\title{
Regulation of Peripheral Nerve Myelin Maintenance by Gene Repression through Polycomb Repressive Complex 2
}

\author{
Ki H. Ma, ${ }^{1,2}$ Holly A. Hung, ${ }^{1,2}$ Rajini Srinivasan, ${ }^{1}$ Huafeng Xie, ${ }^{4}$ Stuart H. Orkin, ${ }^{4}$ and John Svaren ${ }^{1,3}$ \\ ${ }^{1}$ Waisman Center, ${ }^{2}$ Cellular and Molecular Pathology Graduate Program, ${ }^{3}$ Department of Comparative Biosciences, University of Wisconsin-Madison, \\ Madison, Wisconsin 53705, and ${ }^{4}$ Dana Farber Cancer Institute and Boston Children's Hospital, Harvard Medical School and Howard Hughes Medical \\ Institute, Boston, Massachusetts 02115
}

Myelination of peripheral nerves by Schwann cells requires coordinate regulation of gene repression as well as gene activation. Several chromatin remodeling pathways critical for peripheral nerve myelination have been identified, but the functions of histone methylation in the peripheral nerve have not been elucidated. To determine the role of histone H3 Lys27 methylation, we have generated mice with a Schwann cell-specific knock-out of Eed, which is an essential subunit of the polycomb repressive complex 2 (PRC2) that catalyzes methylation of histone H3 Lys27. Analysis of this mutant revealed no significant effects on early postnatal development of myelin. However, its loss eventually causes progressive hypermyelination of small-diameter axons and apparent fragmentation of Remak bundles. These data identify the PRC2 complex as an epigenomic modulator of mature myelin thickness, which is associated with changes in Akt phosphorylation. Interestingly, we found that Eed inactivation causes derepression of several genes, e.g., Sonic hedgehog (Shh) and Insulin-like growth factor-binding protein 2 (Igfbp2), that become activated after nerve injury, but without activation of a primary regulator of the injury program, c-Jun. Analysis of the activated genes in cultured Schwann cells showed that Igfbp2 regulates Akt activation. Our results identify an epigenomic pathway required for establishing thickness of mature myelin and repressing genes that respond to nerve injury.

Key words: chromatin; histone; injury; myelin; polycomb; Schwann

\section{Introduction}

The formation and maintenance of myelin by Schwann cells is dependent upon transcriptional regulation that requires both activation and repression of genes (Jessen and Mirsky, 2008; Svaren and Meijer, 2008). While several transcription factors that coordinate the transcriptional network of Schwann cell differentiation are well characterized, the epigenomic modulators required for myelination are only beginning to be elucidated. Previous work has shown that histone deacetylases 1/2 (HDAC 1/2), BRG1, and nucleosome remodeling and deacetylase (NuRD) chromatin remodeling complexes are required for formation and long-term maintenance of stable myelin (Jacob et al., 2011; Hung et al., 2012; Weider et al., 2012). BRG1 interacts with SOX10 and is required for activation of many genes associated with myelina-

Received June 2, 2014; revised April 20, 2015; accepted April 28, 2015.

Author contributions: K.H.M. and J.S. designed research; K.H.M., H.A.H., and R.S. performed research; H.A.H., R.S., H.X., and S.H.O. contributed unpublished reagents/analytic tools; K.H.M., H.A.H., R.S., and J.S. analyzed data; K.H.M. and J.S. wrote the paper.

This work was supported by the National Institutes of Health: NS075269 to J.S. and P30 Core Grant HD03352. We thank Marie Adams for performance and preliminary analysis of Illumina sequencing, Xiao-yu Liu for assistance in ChIP-Seq/microarray analysis, Christopher Huppenbauer for technical support in 3D deconvolution imaging, Steve Scherer for guidance in EM analysis, and Albee Messing and Larry Wrabetz for generously providing the P0-Cre mice. We also thank Bryan Schumacher, Seongsik Won, Karla Knobel, the University of Wisconsin Electron Microscope Facility, and David Gamm for providing microscopy resources.

The authors declare no competing financial interests.

Correspondence should be addressed to John Svaren, 1500 Highland Avenue, Waisman Center, Madison, WI 53705.E-mail:.jpsvaren@wisc.edu.

DOI:10.1523/JNEUROSCI.2257-14.2015

Copyright $\odot 2015$ the authors $\quad 0270-6474 / 15 / 358640-13 \$ 15.00 / 0$ tion (Weider et al., 2012). The absence of HDAC 1/2 in Schwann cells causes a differentiation arrest (Chen et al., 2011; Jacob et al., 2011), while a Schwann cell-specific deletion of the HDAC 1/2associated NuRD complex causes myelination deficits (Hung et al., 2012). HDAC $1 / 2$ and the NuRD chromatin remodeling complex play a role in repression of negative regulators of myelination, but are also involved in gene activation in Schwann cells (Chen et al., 2011; Jacob et al., 2011; Hung et al., 2012). A recent study has also revealed DNA methylome dynamics during Schwann cell development (Varela-Rey et al., 2014). However, the roles of histone modifications specifically involved in gene repression during Schwann cell development have not been elucidated.

Polycomb repressive complex 2 (PRC2) is involved in diverse biological processes, including differentiation, the maintenance of cell identity, proliferation, and embryonic stem (ES) cell plasticity, by coordinating the repression of tissue-inappropriate and stage-inappropriate transcriptional programs (Boyer et al., 2006; Ezhkova et al., 2009, 2011; Aldiri and Vetter, 2012; He et al., 2012). EZH2, a core subunit of PRC2 with methyltransferase activity, catalyzes dimethylation and trimethylation of histone H3 Lys27 (H3K27me2 and H3K27me3). H3K27 methylation recruits downstream regulatory factors to create a transcriptionally repressive chromatin environment (Viré et al., 2006; Stock et al., 2007; Endoh et al., 2008; Ku et al., 2008; Pasini et al., 2008). A loss of nonredundant core subunits of PRC2 (i.e., EED and SUZ12) results in a global loss of H3K27me2 and H3K27me3 (Pasini et 
Table 1. Primer sequences used for $q R T-P C R$ experiments

\begin{tabular}{|c|c|c|}
\hline \multirow[t]{2}{*}{ Sox10 } & Forward & GCCACGAGGTAATGTCCAACA \\
\hline & Reverse & TGGTCCAGCTCAGTCACATCA \\
\hline \multirow[t]{2}{*}{ Egr2 } & Forward & TGCTAGCCCTTTCCGTTGA \\
\hline & Reverse & TCTTTTCCGCTGTCCTCGAT \\
\hline \multirow[t]{2}{*}{ Mpz } & Forward & CCCTGGCCATTGTGGTTTAC \\
\hline & Reverse & CCATTCACTGGACCAGAAGGAG \\
\hline \multirow[t]{2}{*}{ Pmp22 } & Forward & CACGGTCGGAGCATCAGG \\
\hline & Reverse & TCCTTGGAGGCACAGAACACT \\
\hline \multirow[t]{2}{*}{ Sqle } & Forward & GGCTTGAAGAGGATGTATATAGCATA \\
\hline & Reverse & GTCCACTGTGGAAGTGACACAGTT \\
\hline \multirow[t]{2}{*}{ Hmgcr } & Forward & GGATGGTACCGGTGCTCT \\
\hline & Reverse & AGAAACGAACTGTAGCTC \\
\hline \multirow[t]{2}{*}{ Cx32 } & Forward & ACCGCCTCTCACCTGAATACA \\
\hline & Reverse & CTCGCTCAGCAGCTTGTTGAT \\
\hline \multirow[t]{2}{*}{ Pten } & Forward & AGGCTAGCAGTTCAACTTCTGTGA \\
\hline & Reverse & GTCAGTGGTGTCAGAATATCTATAATGATCA \\
\hline \multirow[t]{2}{*}{ Pax6 } & Forward & CAGCAGTTGGGTATTCAGGAAAG \\
\hline & Reverse & CCAGTTCAGGACAGTTACAAAGTGA \\
\hline \multirow[t]{2}{*}{ |s|1 } & Forward & GCTTAAGAGACCCAGAATTTCACGTA \\
\hline & Reverse & GCGTTGGTTTGCAATGTTTTTA \\
\hline \multirow[t]{2}{*}{ Cond1 } & Forward & ACTCCCCACGATTTCATCGA \\
\hline & Reverse & ATCCGCCTCTGGCATTTTG \\
\hline \multirow[t]{2}{*}{ Cdkn2a } & Forward & GAATCTCCGCGAGGAAAGC \\
\hline & Reverse & TGTCTGCAGCGGACTCCAT \\
\hline \multirow[t]{2}{*}{ Cdkn2b } & Forward & CCCTGTGAACTGAAAATGCAGA \\
\hline & Reverse & TGTCGAGCTGGAGGTGACTTC \\
\hline \multirow[t]{2}{*}{ Brn2 } & Forward & CCCTGTACGGCAACGTGTTC \\
\hline & Reverse & GGGCCTCAAACCTGCAGAT \\
\hline \multirow[t]{2}{*}{$\mathrm{Tb} \times 2$} & Forward & CACAAACTGAAGCTGACCAAC \\
\hline & Reverse & GAAGACATAGGTGCGGAAGG \\
\hline \multirow[t]{2}{*}{$\operatorname{lgf} 2 \mathrm{bp} 3$} & Forward & CCCAGTTTGTTGGAGCCATT \\
\hline & Reverse & CCTGTATTCTCCTTACGATG \\
\hline \multirow[t]{2}{*}{$\operatorname{lgf} 2 \mathrm{bp} 1$} & Forward & CGGCAACCTCAACGAGAGT \\
\hline & Reverse & GTAGCCGGATTTGACCAAGAA \\
\hline \multirow[t]{2}{*}{$\operatorname{lgfbp2}$} & Forward & GCGGGTACCTGTGAAAAGAG \\
\hline & Reverse & CCTCAGAGTGGTCGTCATCA \\
\hline \multirow[t]{2}{*}{ Cspg5 } & Forward & ATGAGACCTCGTGGACAGAG \\
\hline & Reverse & CACTAGGCTTATCATGGACAGC \\
\hline
\end{tabular}

al., 2004; Montgomery et al., 2005), and PRC2 mutants display developmental and proliferative abnormalities, which lead to embryonic lethality during the gastrulation stage in mouse (Faust et al., 1995; O'Carroll et al., 2001; Pasini et al., 2004).

In the following experiments, we investigated the function of H3K27me3 in peripheral nerve by creating a Schwann cellspecific deletion of Eed, an indispensable subunit of the PRC2 complex. Surprisingly, peripheral nerve Eed inactivation does not visibly affect myelination in the early postnatal period, but does cause abnormal gene expression and structural defects, including progressive hypermyelination and morphology changes affecting both myelinating and nonmyelinating Schwann cells (nmSCs). Our results demonstrate a role for the PRC2 epigenomic pathway in regulating myelin maturation.

\section{Materials and Methods}

Antibodies and primer sequences. The antibodies and primers are listed in Tables 1 and 2 .

Experimental animals. Mouse experiments were performed according to protocols approved by the University of Wisconsin School of Veterinary Medicine. Eed-floxed mice (C57/CD1/129 mixed background) and $\mathrm{mP}_{0}$ TOTA-Cre (FVB/N, P0-Cre) mice were genotyped as described previously (Feltri et al., 1999; Xie et al., 2014). Samples collected from mice homozygous for floxed Eed served as control in this study, except for 7 month sciatic nerve samples used in electron micrograph (EM) analysis. Eed conditional knock-out mutants and littermates with a null/null,
Table 2. Antibodies used for immunohistochemistry and Western blots

\begin{tabular}{lll}
\hline Antibody & Catalog number & Company \\
\hline$\beta$-Actin & ab8226 & Abcam \\
Akt & 4691 & Cell Signaling Technology \\
Phospo-Akt & 9275,13038 & Cell Signaling Technology \\
ERK 1/2 & 4695 & Cell Signaling Technology \\
Phospo-ERK 1/2 & 4370 & Cell Signaling Technology \\
KR0X-20 (EGR2) & PRB-236P & Covance \\
PMP22 & Ab61220 & Abcam \\
SOX10 & AF2864 & R\&D Systems \\
H3K27me3 & AM39155 & Active Motif \\
H3K27me3 & $07-449$ & Millipore \\
GFAP & Z0334 & Dak0 \\
SUZ12 & 37375 & Cell Signaling Technology \\
\hline
\end{tabular}

null/floxed, or floxed/floxed Eed allele were used as controls for this time point and nerves from wild-type littermates were indistinguishable in EM analysis. Littermates were used as a control in most experiments.

Immunohistochemistry. Freshly dissected nerves were embedded in Tissue-Tek OCT compound (Sakura Finetek) and snap frozen with liquid nitrogen. Longitudinal or transverse cryostat sections $(14 \mu \mathrm{m})$ were air dried for $5 \mathrm{~min}$ and fixed in $4 \%$ paraformaldehyde for $15 \mathrm{~min}$. The sections were then blocked in PBS containing 5\% donkey serum $/ 1 \%$ $\mathrm{BSA} / 3 \%$ Triton X-100 for $1 \mathrm{~h}$ at room temperature. Primary antibody incubation was performed overnight at $4^{\circ} \mathrm{C}$ in PBS containing $5 \%$ donkey serum $/ 1 \%$ BSA $/ 1 \%$ Triton X-100 and secondary incubation was performed in PBS at room temperature for $1 \mathrm{~h}$. Hoechst 33342 (1:5000 in PBS; Sigma-Aldrich) was applied to stain nuclei for $1 \mathrm{~min}$. Three $4 \mathrm{~min}$ washes were performed in PBS after fixation and blocking, and in PBS containing $0.1 \%$ Tween 20 after primary antibody incubation and nuclear staining. After coverslips were mounted using Fluoromount-G (SouthernBiotech), sections were examined on a confocal microscope (Nikon A1R-Si).

Western blot. Freshly dissected nerves were snap frozen with liquid nitrogen and crushed in dry ice. The nerves were then homogenized in lysis buffer [50 mm Tris- $\mathrm{HCl}, \mathrm{pH} 6.8,10 \%$ glycerol, $2 \%$ SDS, $10 \%$ $\beta$-mercaptoethanol, $50 \mathrm{~mm} \mathrm{NaF}, 1 \mathrm{~mm} \mathrm{Na}_{3} \mathrm{VO}_{4}$, and protease inhibitor mixture (Sigma-Aldrich, P8340)] using a motorized pellet pestle. Cells in culture were homogenized in $3 \times$ lysis buffer. After a 15 min incubation in ice, lysates were boiled at $95^{\circ} \mathrm{C}$ for $3 \mathrm{~min}$ and centrifuged at $4^{\circ} \mathrm{C}$ for 15 min. Subsequently, supernatants were collected and subjected to SDSPAGE. After transfer to nitrocellulose membrane, proteins were blocked in TBST containing 5\% nonfat dry milk for $1 \mathrm{~h}$ at room temperature. Primary and secondary antibody incubations were performed in TBST containing $5 \%$ nonfat dried milk at $4^{\circ} \mathrm{C}$ overnight and at room temperature for $1 \mathrm{~h}$, respectively. Three 5 min washes were performed in TBST after the incubations. The membranes were scanned and quantitated with the Odyssey Infrared Imaging System (Li-Cor Biosciences). Statistical analyses were evaluated by one-way ANOVA.

Electron microscopy and morphometric quantification. Freshly dissected sciatic nerves were immersion fixed in a solution of $2.5 \%$ glutaraldehyde, $2.0 \%$ paraformaldehyde in $0.1 \mathrm{~m}$ sodium phosphate buffer, $\mathrm{pH} 7.4$, overnight at $4^{\circ} \mathrm{C}$. The nerves were then postfixed in $1 \%$ osmium tetroxide in the same buffer for $2 \mathrm{~h}$ at room temperature. Following OsO4 postfixation, the nerves were dehydrated in a graded ethanol series, and then further dehydrated in propylene oxide and embedded in Epon or Durcupan epoxy resin. Ultrathin transverse sections were contrasted with Reynolds lead citrate and $8 \%$ uranyl acetate in $50 \% \mathrm{EtOH}$ and observed with a Philips CM120 electron microscope and captured with a MegaView III side-mounted digital camera at the University of Wisconsin Medical School Electron Microscope Facility. Three mice per genotype were analyzed, and statistical analyses were evaluated by one-way ANOVA in all the experiments.

Cell culture conditions and transfection assays. Primary rat Schwann cells (RSCs) and the RT4-D6P2T rat Schwann cell line (obtained from ATCC) were maintained in DMEM supplemented with $5 \%$ bovine growth serum (Hyclone) and with or without $2 \mu \mathrm{M}$ forskolin and 0.02 
$\mu \mathrm{g} / \mathrm{ml}$ bovine pituitary extract (Sigma-Aldrich), respectively. Transfection assays were performed with RNAiMAX transfection reagent (Life Technologies) according to the manufacturer's protocol, using DsiRNA Duplexes targeting Insulin-like growth factor-binding protein 2 (Igfbp2; Integrated DNA Technologies, reference \#128891524, \#28891527) in culture media, and protein and RNA were isolated $48 \mathrm{~h}$ after transfection. RSCs were washed once in serum-free media and cultured overnight in serum-free growth medium (DMEM/F12 1:1; Life Technologies), $1 \times$ insulin-transferrin-sodium selenite medium supplement (SigmaAldrich, I1884). Then, $20 \mathrm{ng} / \mathrm{ml}$ neuregulin- $1 \beta$ isoform (heregulin- $\beta 1$; R\&D Systems) was added to the media $20 \mathrm{~min}$ before the isolation. One microgram of RNA isolated from the transfected cells using Tri Reagent (Ambion) was subjected to qRT-PCR.

$q R T-P C R$. RNA was isolated from sciatic nerves using RNeasy Lipid Tissue Mini Kit (Qiagen) according to the manufacturer's directions. To prepare cDNA, $250 \mathrm{ng}$ of total RNA was used from each sample. qRTPCR and data analysis were performed as described previously (Hung et al., 2012). Statistical analyses were evaluated by one-way ANOVA.

Micrococcal nucleases-aided chromatin immunoprecipitation in vivo. The snap-frozen sciatic nerves [postnatal day (P) 30] were ground and incubated in $1 \mathrm{ml}$ of a modified lysis buffer 1 (50 mM HEPES-KOH, pH 7.5; $140 \mathrm{~mm} \mathrm{NaCl} ; 4 \mathrm{~mm} \mathrm{MgCl}$; 10\% glycerol; 0.5\% Igepal CA-630; $0.25 \%$ Triton X-100; protease inhibitor mixture; Schmidt et al., 2009) for $20 \mathrm{~min}$ at $4^{\circ} \mathrm{C}$ on rotator. After 15 strokes with a Dounce homogenizer, samples were centrifuged at $18,000 \times$ relative centrifugal force $(\mathrm{rcf})$ for $10 \mathrm{~min}$ at $4^{\circ} \mathrm{C}$. Pellets were washed with $1 \mathrm{ml}$ of micrococcal nucleases (MNase) digestion buffer ( $0.32 \mathrm{M}$ sucrose; $50 \mathrm{~mm}$ Tris- $\mathrm{HCl}, \mathrm{pH} 7.5 ; 4 \mathrm{~mm}$ $\mathrm{MgCl}_{2} ; 1 \mathrm{mM} \mathrm{CaCl}_{2}$; protease inhibitor mixture) as described previously (Umlauf et al., 2004). After pelleting insoluble material by centrifugation, samples were resuspended in $200 \mu \mathrm{l}$ of MNase digestion buffer and incubated with $1 \mu \mathrm{l}$ (2000 gel units) of MNase (New England Biolabs, $\mathrm{M} 0247$ ) for $7 \mathrm{~min}$ at $37^{\circ} \mathrm{C}$. Digestion was terminated by addition of EDTA to a final concentration of $0.05 \mathrm{M}$. Samples were centrifuged at $18,000 \times$ rcf for $20 \mathrm{~min}$ at $4^{\circ} \mathrm{C}$, and supernatants containing small fragments of chromatin were pooled. The majority of digested chromatin was $\sim 150$ bp (data not shown). Each aliquot of chromatin containing $\sim 1.5 \mu \mathrm{g}$ of DNA was incubated with $5 \mu \mathrm{g}$ of antibodies in chromatin immunoprecipitation (ChIP) incubation buffer $(50 \mathrm{~mm} \mathrm{NaCl} ; 50 \mathrm{~mm}$ Tris- $\mathrm{HCl}, \mathrm{pH} 7.5$; protease inhibitor mixture; $5 \mathrm{~mm}$ EDTA) that completed the volume to $1 \mathrm{ml}$ for $12-16 \mathrm{~h}$ at $4^{\circ} \mathrm{C}$ on rotator. Eighty microliters of Dynabeads Protein G (Invitrogen, 10004D) slurry was washed twice with $0.5 \%$ BSA in PBS and then incubated with each ChIP sample for $4 \mathrm{~h}$ at $4^{\circ} \mathrm{C}$ on rotator. ChIP samples were washed five times in RIPA buffer and then eluted at $65^{\circ} \mathrm{C}$ with elution buffer $(50 \mathrm{~mm} \mathrm{NaCl} ; 50 \mathrm{~mm}$ Tris-HCl, pH 7.5; 5 mm EDTA; 1\% SDS) for $15 \mathrm{~min}$. DNA was purified by phenol chloroform extraction and subjected to qPCR. Statistical analyses were evaluated by one-way ANOVA.

ChIP-seq. In vivo ChIP assays for histone modifications were performed as previously described (Jang et al., 2006) with slight modifications. Freshly dissected mouse sciatic nerves from 12 8-week-old male mice were minced in $1 \%$ formaldehyde for $10 \mathrm{~min}$ and then quenched for 10 min with glycine to a final concentration of 0.125 M. Samples were sequentially lysed in buffers as described previously (Schmidt et al., 2009). Chromatin was fragmented using four repetitions of $10 \mathrm{~min}$ Bioruptor (Diagenode) cycle (30 s on; $30 \mathrm{~s}$ off) at the medium setting. Each aliquot of sonicated chromatin that contained $300 \mu \mathrm{g}$ of proteins was incubated with $5 \mu \mathrm{g}$ of antibodies overnight at $4^{\circ} \mathrm{C}$ on rotator, followed by subsequent steps stated above. Library preparation and sequencing was performed by the University of Wisconsin Biotechnology Center on an Illumina HiSeq 2000. Base calling was performed using the standard Illumina Pipeline. Reads were mapped to the mouse genome mm10 using Bowtie. There were a total of 47 and 30 million reads mapped in the input and in the H3K27me3 ChIP sample, respectively. The raw data files are deposited in National Center for Biotechnology Information Gene Expression Omnibus under accession number GSE64260. Hypergeometric optimization of motif enrichment (HOMER; Heinz et al., 2010) was used to determine enriched binding regions for H3K27me3-ChIP relative to sequencing of an input chromatin sample. Peaks called with HOMER used a minimum peak cutoff score of 25 .
Microarray analysis. Total RNA isolated from 4 month sciatic nerves of three mice of each genotype were processed for microarray analysis using Mouse Ref-8v2 BeadChips (Illumina) by the University of Wisconsin Biotechnology Center. Raw microarray images were processed by Illumina Genome Studio. Probe intensity data were exported for background correction, variance stabilizing transformation, and quantile normalization by R/Bioconductor package lumi (Du et al., 2008). To identify differentially expressed genes, the Limma package (Wettenhall and Smyth, 2004) was used to compute the fold change between conditional knock-out (cKO) and control samples and its $p$ value with linear regression models.

\section{Results}

\section{Conditional inactivation of Eed in Schwann cells}

To address the function of the epigenomic repression mediated by H3K27me3 in peripheral nerves, we developed a mouse model that conditionally inactivates the Eed gene in Schwann cells. EED is the PRC2 subunit that binds $\mathrm{H} 3 \mathrm{~K} 27 \mathrm{me}$, and its binding is required for allosteric activation of the methyltransferase activity of EZH2, generating a positive feedback loop to propagate H3K27me3 (Margueron et al., 2009). Importantly, a targeted deletion of EED has been shown to abolish H3K27 trimethylation in ES cells (Montgomery et al., 2005). Deletion of EED was chosen since loss of the EZH2 catalytic subunit can be compensated by the redundant catalytic subunit EZH1 (Shen et al., 2008; He et al., 2012). The mutant mice were generated with Eed exons 3-6 flanked with loxP sites (Xie et al., 2014) and were mated to P0-cre mice, in which cre recombinase expression is driven by the Schwann cell-specific promoter of $P O / M p z$ at embryonic day 15/16 (Feltri et al., 1999). Deleted exons encode two of five repeating WD-40 motifs of the protein, and deletion of any of the five motifs abolishes the catalytic activity of the PRC2 (Montgomery et al., 2007). Additionally, the recombination leads to a frameshift mutation that would eliminate functional EED.

Mice with Schwann cell-specific deletion of Eed were viable and initially had no discernible motor phenotype. qRT-PCR analysis demonstrated significantly reduced Eed mRNA expression in Eed cKO nerves compared with control nerves (Fig. 1A). The expression of Suz12, another core subunit of PRC2, was unaffected. The residual Eed mRNA is presumably due to other cells in sciatic nerves, such as endothelial cells and fibroblasts. Immunohistochemistry confirmed that nuclear staining of H3K27me3 was markedly reduced specifically in SOX10-positive Schwann cells of Eed cKO nerves at P15, whereas H3K27me3 levels in non-Schwann cells were unaltered (Fig. 1B). However, we noticed subnuclear regions with a residual H3K27me3 signal, shown as speckles, in Eed cKO Schwann cell nuclei. These speckles seemed to colocalize with the bright spots of Hoechst-stained nuclei, which are presumably associated with heterochromatin foci (Miller et al., 1974; Peters et al., 2003). To rule out the possibility of nonspecific signal, another antibody targeting H3K27me3 was used and showed similar results (data not shown). Both antibodies used in this analysis have been shown to be specific to H3K27me3 (Egelhofer et al., 2011). Additionally, persistent staining in the absence of Hoechst stain (data not shown) indicated the speckles were not due to a bleed-through artifact from Hoechst fluorescence emission. The persistence of residual H3K27me3 can be explained by the possibility that inactivation of Eed gene occurs after the establishment of the histone mark in embryonic Schwann cell development. In the absence of active demethylation, existing methylated histones are distributed to daughter DNA strands, leading to dilution (but not elimination) of $\mathrm{H} 3 \mathrm{~K} 27 \mathrm{me} 3$ by newly synthesized histone $\mathrm{H} 3$ during cell divisions without a functional PRC2 (Hansen et al., 2008; 
A

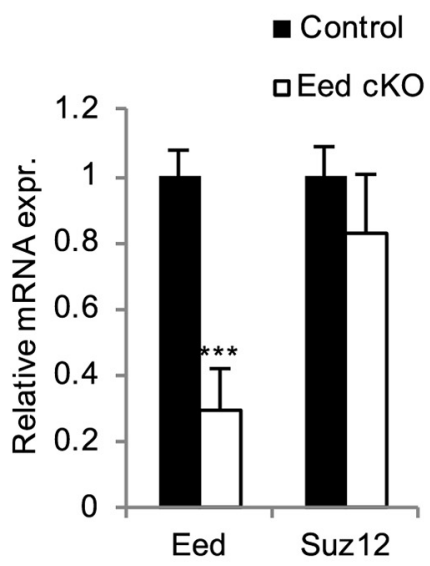

B

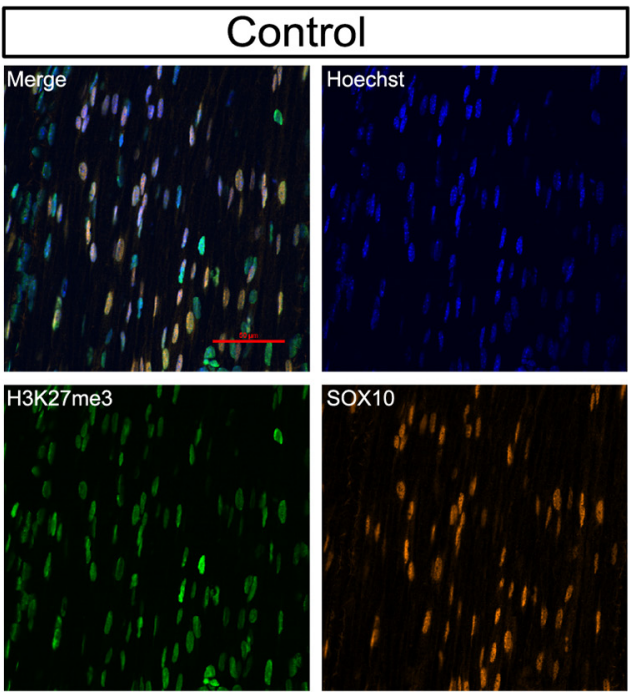

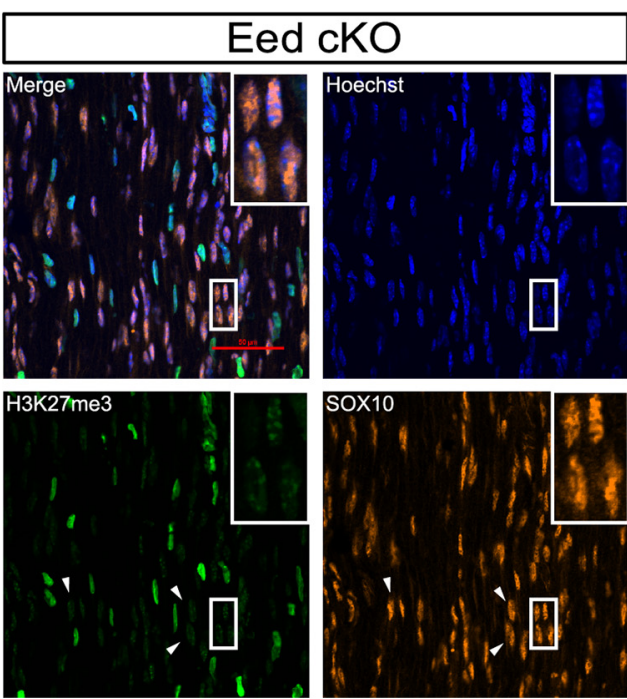

Figure 1. Schwann cell-specific deletion of Eed results in reduction of H3K27me3. $A$, RNA was purified from Eed cK0 and control sciatic nerves at P30 and analyzed for Eed and Suz12 expression relative to $18 \mathrm{~S}$ rRNA using qRT-PCR. Expression level of each gene in wild-type nerve is set as 1. Error bars, \pm SD; ${ }^{* * *} p<0.00001 ; n=4$ for control; $n=5$ for Eed cK0. $\boldsymbol{B}$, Immunohistochemistry on longitudinal sections of P15 sciatic nerves was performed for SOX10 (orange) and H3K27me3 (green) and also costained with Hoechst (blue). Arrowheads indicate Eed cKO Schwann cells with normal levels of SOX10 but greatly diminished levels of H3K27me3. The inset shows that residual H3K27me3 in Eed cKO Schwann cells is localized in speckles at heterochromatic foci of these nuclei.

Lanzuolo et al., 2011). H3K27me3 level is therefore reduced globally, but residual $\mathrm{H} 3 \mathrm{~K} 27 \mathrm{me} 3$ is still detectable in chromatin dense regions.

\section{Progressive hypermyelination and morphology changes in Eed-deficient peripheral nerves}

Electron microscopy of Eed cKO sciatic nerves showed an apparent hypermyelination of smaller-diameter axons (1-3 $\mu \mathrm{m})$, compared with control nerves at 2 and 7 months (Fig. $2 A$ ). Because myelin thickness is proportional to axon diameter, myelin sheaths normally appear with clear contrast between thicker myelin sheaths of large-diameter axons and thinner myelin sheaths of small-diameter axons. Quantitative analysis revealed that the $g$-ratio (diameter of axon/outer diameter of myelinated fiber) in 2 month Eed cKO nerves was significantly lower than control nerves for axons $<2 \mu \mathrm{m}$ in diameter, indicating thicker myelin sheaths in Eed cKO nerves (Fig. 2B). At 7 months, the hypermyelination was detected in axons $\leq 4 \mu \mathrm{m}$ in diameter. No apparent difference between control and Eed cKO nerves was observed at P15. This analysis suggests that Eed cKO nerves develop a progressive hypermyelination with age. Such hypermyelination was mainly due to additional layers of myelin rather than altered periodicity of myelin (data not shown). The axon size distribution was not statistically different between the two groups at both time points (data not shown).

We also noticed an increase of myelin abnormalities in 7 month Eed cKO nerves, such as infolding, outfolding, and tomacula (Fig. 2C). Myelin outfoldings wrapped partially around the original myelin sheath (Fig. 2Ci) or formed myelin columns parallel to the original ones (Fig. 2Cii). Myelin infoldings appeared as single, double, or triple myelin rings within a myelinated axon (Fig. 2Ciii,Civ). Tomacula were formed by excess myelin membrane around axons being fused to the original myelin sheath (Fig. 2Cvi). Less frequently, there was also evidence of axonal degeneration (Fig. 2Cvii) and increased incidence of polyaxonal myelination in Eed cKO nerves compared with control nerves (Fig. 2Cviii). Polyaxonal myelination, in which clus- ters of small axons are enclosed by a thin myelin sheath, is occasionally evident during the active myelination period in wild-type mice, but generally becomes corrected in adult nerves (Rasi et al., 2010). These myelin pathologies were somewhat increased in number with age (Fig. 2D), but myelin infolding accounted for $90 \%$ of pathologies in 7 month Eed cKO nerves. Additionally, quantification of myelinated fibers showed a significantly decreased number of myelinated fibers in Eed cKO nerves at 7 months, but not at 2 months (Fig. $3 F$; data not shown). These results suggest that the function of PRC2 is important for myelin homeostasis, and that the dysregulation leads to hypermyelination of small-diameter axons $(1-4 \mu \mathrm{m})$ and focal myelin pathology in adult nerves.

Remak bundle fragmentation and loss of unmyelinated axons in Eed-deficient peripheral nerves

Electron microscopy of transverse sections of 7 month Eed cKO nerves revealed many isolated small-diameter axons that were wrapped by individual processes of nmSCs (Fig. 3A). Quantification of unmyelinated axon distribution showed that Remak bundles enclosed fewer numbers of axons $(<8)$ in 2 month Eed cKO nerves compared with controls. This feature had progressed with age such that isolated processes with a single axon became more prevalent in 7 month Eed cKO nerves (Fig. 3C). Accordingly, the number of Remak bundles enclosing large numbers of axons $(>15)$ was significantly lower in Eed cKO nerves.

We considered whether Eed cKO nerves had an increased number of nmSCs wrapping the small-diameter axons, generating Remak bundles enclosing smaller numbers of axons than control nerves. However, quantification showed that the number of nmSC nuclei per section was not significantly different at 7 months when Remak bundle fragmentation was apparent (Fig. $3 E)$. The second possibility would be that Eed deficiency results in change of nmSC morphology. We observed Remak bundles that were bridged by a narrow section of nmSC cytoplasm and nmSCs sending a single process to a distant axon in EM cross sections of Eed cKO nerves (Fig. 3Bi-Biii). To further analyze these abnor- 
A
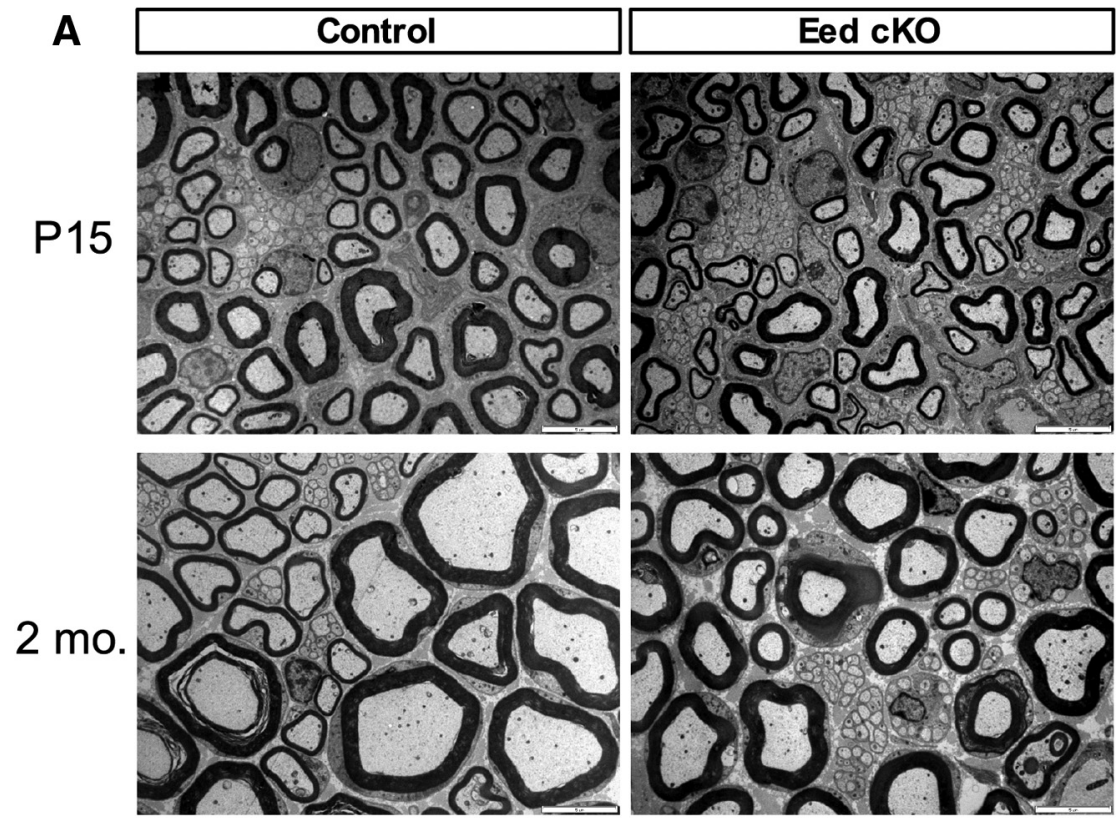

7 mo.
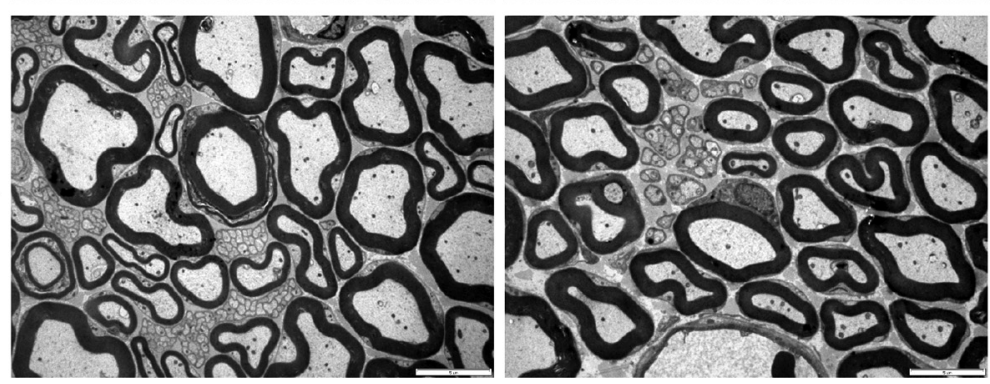

B
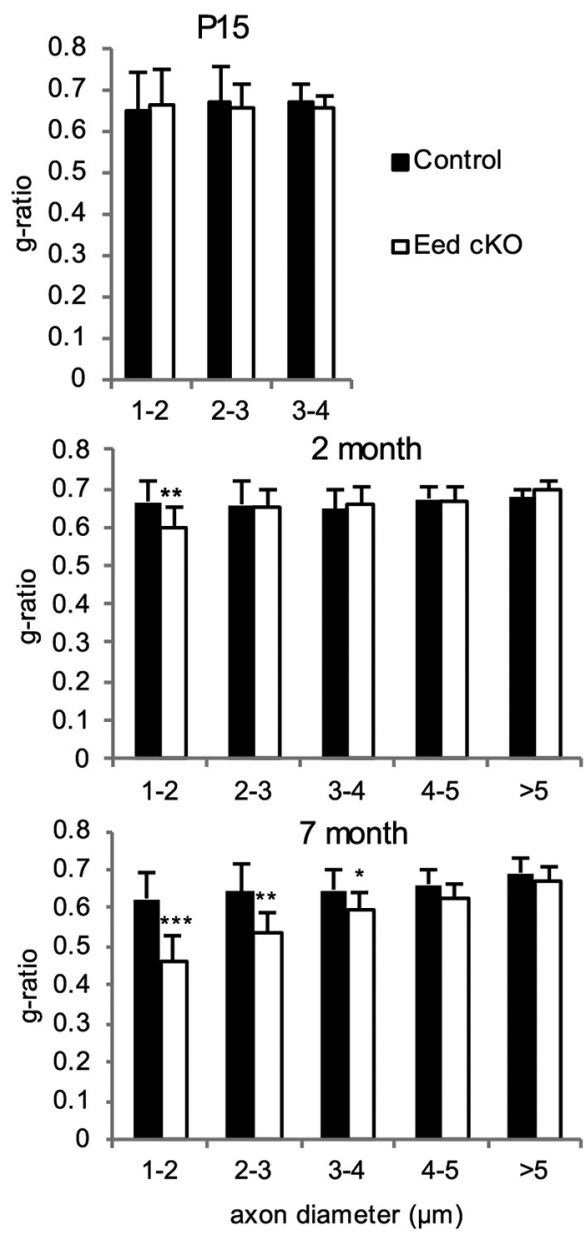
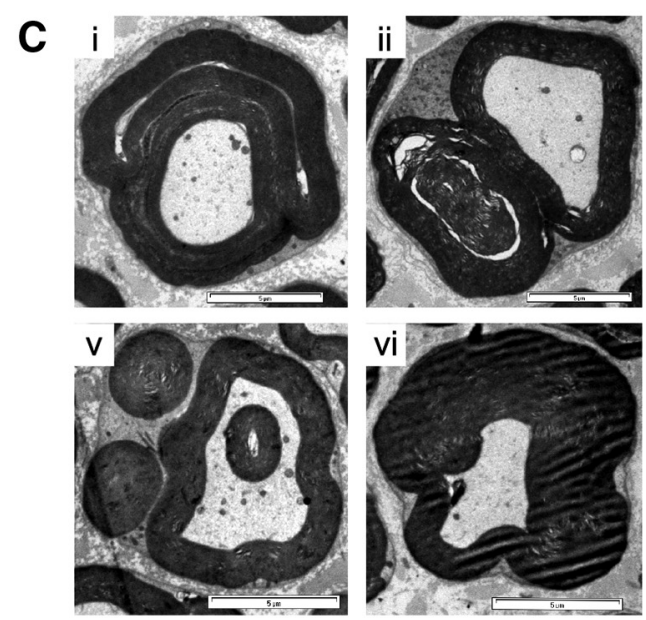
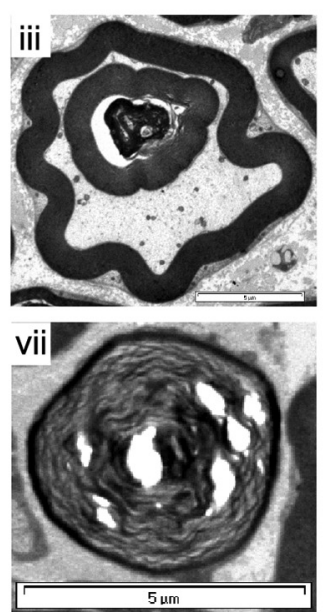
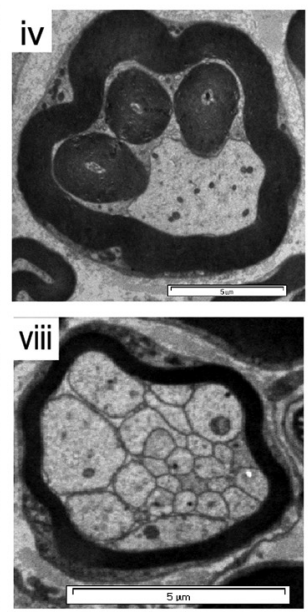

D

\section{Myelin pathology}

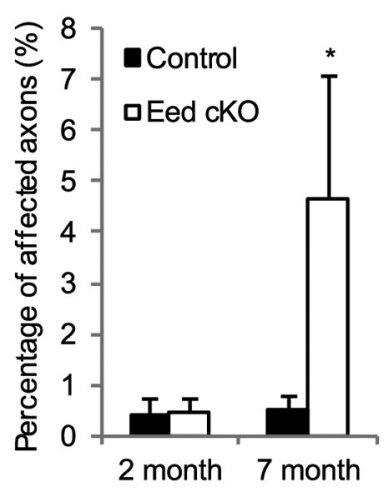

Figure 2. Eed cKO nerves develop progressive hypermyelination. $\boldsymbol{A}$, EMs of Eed cKO sciatic nerves compared with control nerves at the indicated ages. Scale bars, $5 \mu \mathrm{m}$. $\boldsymbol{B}$, For $g$-ratio analysis (axon diameter/diameter of myelinated fiber), the diameter of axon and outer diameter of myelinated fiber were measured on $>380$ randomly selected fibers per genotype. Data: weighted mean \pm pooled SD; ${ }^{* * *} p<0.0001,{ }^{* *} p<0.005,{ }^{*} p<0.05 ; n=3$ per genotype and age. C, Numerous large-diameter axons $(>2 \mu \mathrm{m})$ of 7 month mutant nerves exhibit focal hypermyelination, such as myelin outfolding $(\boldsymbol{i}, \boldsymbol{i} i)$, myelin infolding shown as single, double, or triple myelin rings within a myelinated axon (iii, iv), myelin loops (v), tomacula (vi), Wallerian-type degeneration (vii), and polyaxonal myelination (viii). Scale bars, $5 \mu \mathrm{m}$. D, Fibers with myelin abnormalities were quantified as a percentage of $>3000$ randomly selected fibers per genotype. Data: mean $\pm S D ;{ }^{*} p<$ $0.05 ; n=3$ per genotype and age.

malities, we used 3D deconvolution imaging of transverse sections of nerves stained with glial fibrillary acidic protein (GFAP, a marker for nmSCs). The reconstructed images showed that the processes of Eed cKO nmSCs were separated in some planes of the $z$-axis and formed a few tapered branches, whereas those of control nmSCs remained bundled throughout the $z$-axis (Fig. $3 D$ ). Together, these observations suggest that Remak bundle fragmentation seen in Eed cKO nerves was mainly due to altered 
A
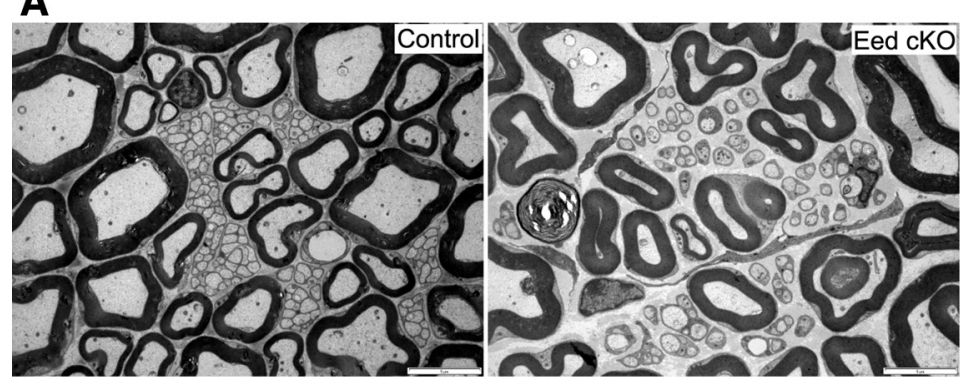

\section{B}

C
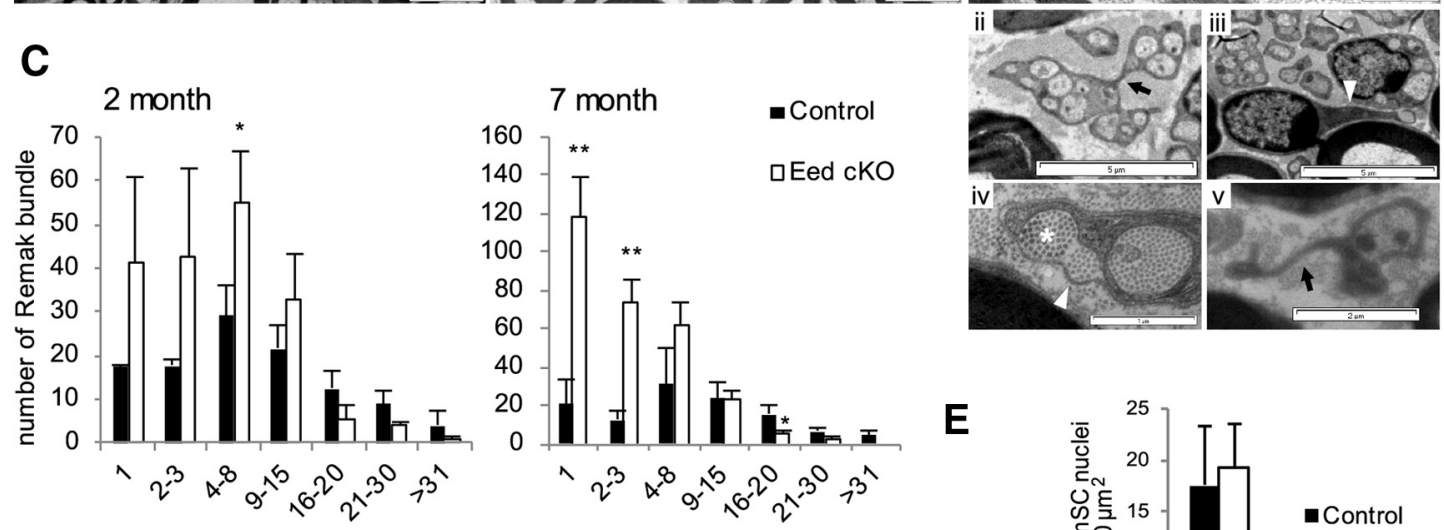

D

number of axons / Remak bundle
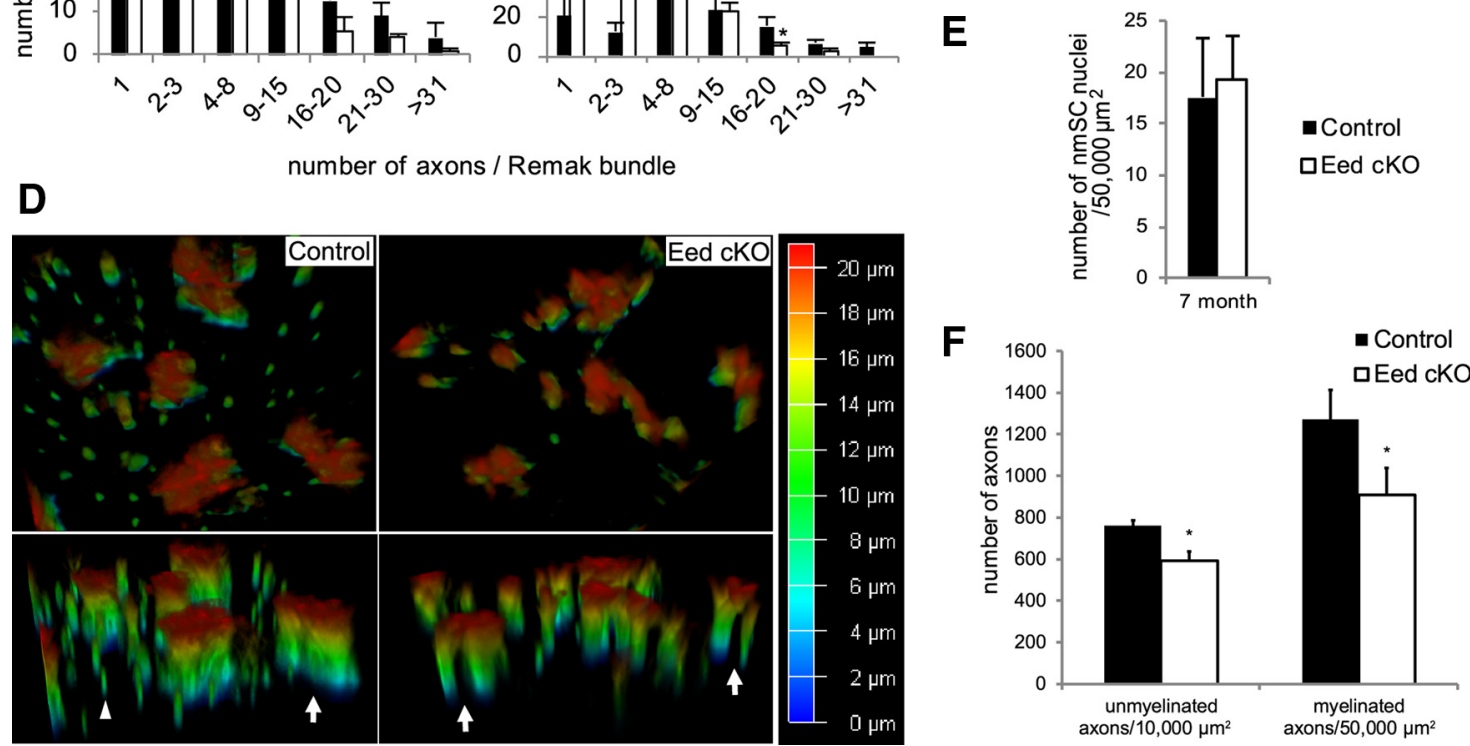

Figure 3. Eed cKO nerves show Remak bundle fragmentation and the morphology change of nmSCs. A, EMs show fragmentation of Remak bundles in 7 month Eed cKO sciatic nerves compared with control nerves. Scale bars, $5 \mu \mathrm{m}$. B, EM of 7 month Eed cKO sciatic nerve. Arrows in $\boldsymbol{i}$ and $i \boldsymbol{i}$ point to where nmSC processes separate out to form two branches. An arrowhead in iii points to a single long process reaching a distant axon from a cell body. An asterisk in iv points to a collagen pocket, which is collagen surrounded by a nmSC process and a basal lamina (arrowhead). An arrow in $\boldsymbol{v}$ points to a free nmSC process. Scale bars: $\boldsymbol{i}, \boldsymbol{i v}, 1 \mu \mathrm{m} ; \boldsymbol{v}, 2 \mu \mathrm{m} ; \boldsymbol{i i}, \mathbf{i i i}, 5 \mu \mathrm{m}$. C, The numbers of Remak bundles that are associated with $>1000$ randomly selected axons in control and Eed cK0 sciatic nerves were grouped into seven categories based on the number of bundled axons. D. Transverse cryosections of sciatic nerves were stained with GFAP antibody and imaged using 3D deconvolution (color code indicates depth in the $z$-axis). The processes of Eed cKO nmSCs are separated while those of control nmSCs are in a bundle (arrows). An arrowhead indicates nonspecific staining. $E$, nmSC nuclei were counted in randomly selected fields that accounted for $>45 \%$ of an entire sciatic nerve cross section from each animal and normalized per surface area $\left(50,000 \mu \mathrm{m}^{2}\right)$. $F$, Unmyelinated and myelinated axons were counted in randomly selected fields that accounted for $>8$ and $44 \%$ of an entire sciatic nerve cross section from each animal and normalized per surface area $\left(10,000\right.$ and $\left.50,000 \mu \mathrm{m}^{2}\right)$, respectively. Fields that contain $<15$ unmyelinated axons were omitted for this quantification. Data: mean $\pm S D ;{ }^{* *} p<0.005,{ }^{*} p<0.05 ; n=3$ per genotype.

nmSC morphology. We frequently observed Remak bundles that partly wrapped collagen fibrils and nmSCs exhibiting free Schwann cell processes that did not associate with axons in Eed cKO nerves (Fig. 3Biv, Bv). Of note, the presence of basal lamina seen in Figure 3Biv (arrowhead) is likely derived from the original border of the Remak bundle. Additionally, this abnormality was correlated with a loss of unmyelinated axons. Quantification showed a significantly lower number of unmyelinated axons per surface area in 7 month Eed cKO nerves (Fig. $3 F$ ), whereas no significant difference was observed at 2 months (data not shown).
Altered gene expression in peripheral nerves of Eed cKO mice Hypermyelination could reflect a heightened activation of myelin-related genes. However, qRT-PCR analysis revealed that several myelin genes, including Egr2/Krox20, a major transcriptional regulator of myelination (Topilko et al., 1994; Le et al., 2005; Decker et al., 2006), were slightly lower in the Eed cKO nerves compared with control nerves (Fig. 4A). Therefore, hypermyelination was not due to increased transcriptional activation of myelin genes. Egr2 levels were similarly reduced at P30 (a time point after the peak of myelination but least affected by the structural changes) and 4 months. Interestingly, despite somewhat 


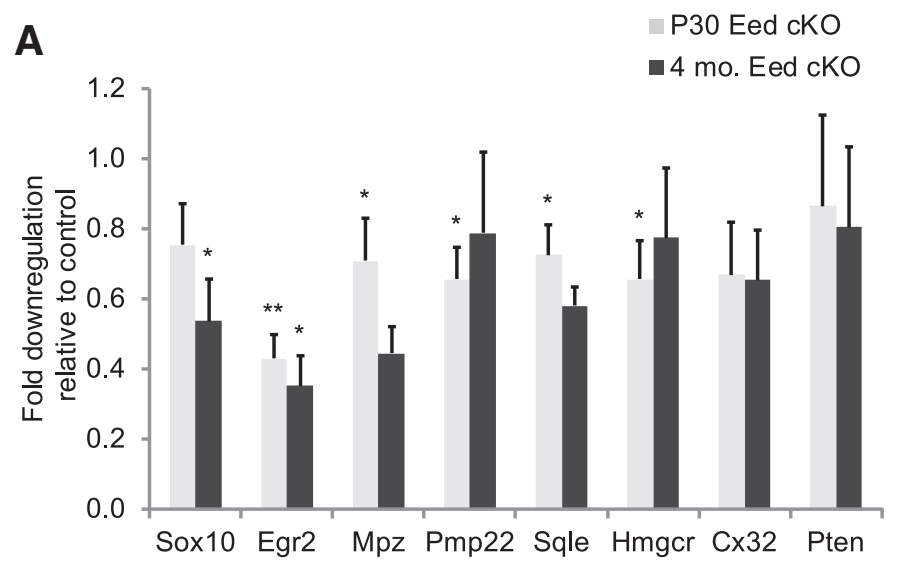

B
\begin{tabular}{|c|c|c|c|}
\hline \multirow{2}{*}{ Gene } & \multirow{2}{*}{$\begin{array}{c}\text { Fold Change } \\
\text { Eed cKO / control }\end{array}$} & Injury response genes \\
\cline { 3 - 4 } & Shh & 4.20 \\
\hline Neuronal Differentiation & Thy 1 & 3.82 \\
\hline Foxs1 & 3.54 & Gjb2 & 3.20 \\
\hline Foxg1 & 1.47 & Mdk & 2.38 \\
\hline Isl1 & 2.28 & Chst8 & 1.88 \\
\hline MPNST-associated genes & Cspg 5 & 1.55 \\
\hline Zic1 & 2.13 & Shh target genes \\
\hline Nkd2 & 2.10 & Bmi 1 & 1.43 \\
\hline Sh3gl2 & 1.75 & Ccnd 1 & 3.17 \\
\hline Dmrta2 & 1.57 & Zic3 & 1.47 \\
\hline
\end{tabular}

C
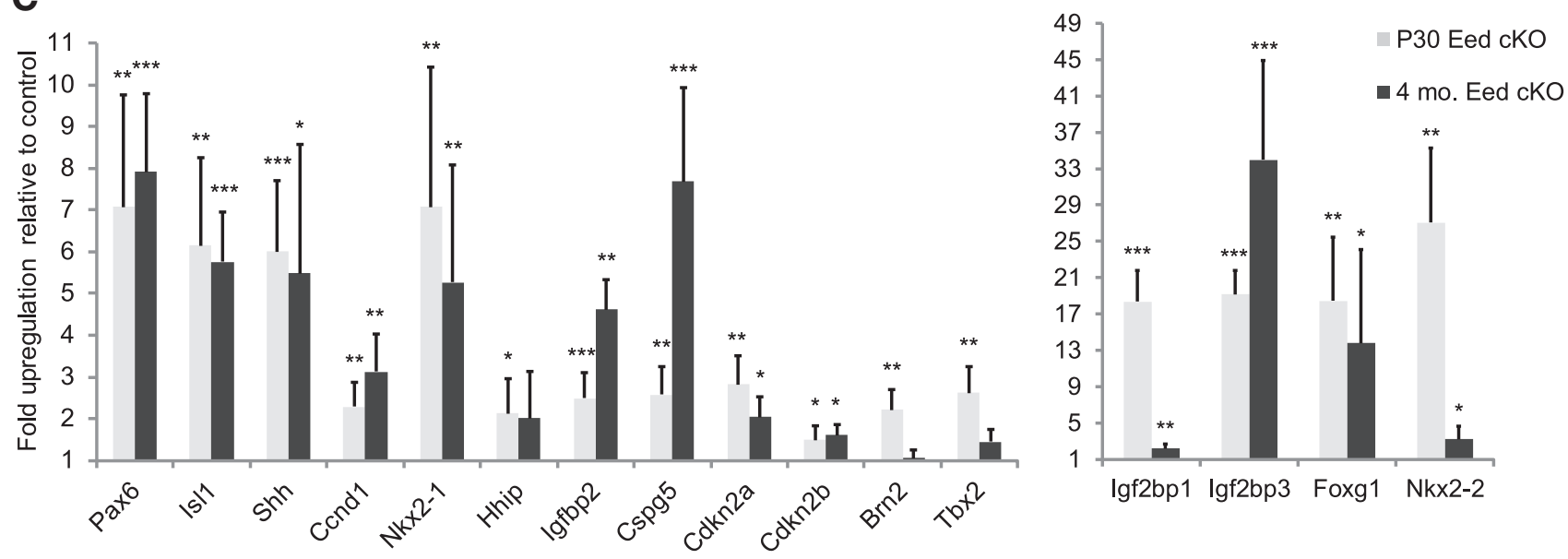

Figure 4. Gene expression analysis of Eed CKO nerves reveals tissue-inappropriate and stage-inappropriate gene expression. A, C, qRT-PCR analysis was used to identify the expression level of myelin-related genes and $P$ ten $(\boldsymbol{A})$ and tissue-inappropriate and stage-inappropriate genes $(\boldsymbol{C})$ at the indicated ages. Control level is 1 at each age (data not shown). Values normalized with $18 \mathrm{~S}$ rRNA. Data: mean $\pm S D ;{ }^{*} p<0.05,{ }^{* *} p<0.005,{ }^{* * *} p<0.0005 ; n=4$ for control, and $n=5$ for Eed cK0 at P30, and $n=5$ per genotype at 4 months. $\boldsymbol{B}$, Microarray analysis identified the induction of injury-response genes, Shh downstream genes, neuronal transcription factors, and MPNST-associated genes among derepressed genes in 4 month Eed cKO nerves. Injury-response genes were identified by genes upregulated $7 \mathrm{~d}$ after nerve cut in published microarray data (Arthur-Farraj et al., 2012). Data: average fold-change of three mice per genotype with adjusted $p$ value $<0.05$.

lower mRNA levels of Egr2 and other myelin genes, we found no significant differences in the protein levels of EGR2 and PMP22 (Fig. 5A,B). Therefore, the modest transcriptional downregulation of myelin genes did not markedly affect protein levels.

To identify the spectrum of altered gene expressions in Eed cKO nerves, we measured gene expression in sciatic nerves by microarray. The resulting patterns did not reveal large-scale expression changes, but rather induction of specific gene subsets. Interestingly, we found that $30 \%$ of genes upregulated by Eed ablation ( $>1.5$-fold, total 108 genes) overlapped with genes that become activated after nerve injury (Arthur-Farraj et al., 2012). This included such genes as Thy1, Gjb2, Mdk, Cspg5, Chst8, Igfbp2, and Sonic hedgehog (Shh; Fig. 4B,C). The activation of several of these genes following nerve injury was recently shown to be c-Jun dependent (Arthur-Farraj et al., 2012). However, c-Jun mRNA was not altered, and there was not general induction of c-Jun-dependent injury-response genes, such as $G d n f, B d n f$, and $\mathrm{Ngfr} / \mathrm{p} 75$ (also tested by qRT-PCR; data not shown), suggesting that such induction was not mediated by c-Jun activation in the Eed cKO nerves. Sh h is among the most highly activated genes on the first day after injury and regulates nerve regeneration by promoting neuronal survival (Hashimoto et al., 2008; Kim et al., 2012). Increased Shh was correlated with induction of previously described hedgehog target genes, such as Bmil, Cyclin D1 (Ccnd1), Zic3, Nkx2-1, Nkx2-2, and Hhip (Chuang and McMa- hon, 1999; Kenney and Rowitch, 2000; Pabst et al., 2000; Leung et al., 2004; Vokes et al., 2007).

Functional annotation of disregulated genes revealed genes involved in early specification of neuronal differentiation included Isl1, Shh, Foxs1, and Foxg1 (Montelius et al., 2007; Huang et al., 2009a,b). Further analysis by qRT-PCR confirmed a significant induction of these genes and also Pax6 in Eed cKO nerves (Fig. 4C). The Cdk inhibitors $(C d k n 2 a / 2 b)$ and neuronal transcription factors (Isl1, Foxg1, Pax6) have been shown to be targets of polycomb repression in other tissues (Chen et al., 2009; Ezhkova et al., 2011; He et al., 2012). We also identified the derepression of genes that are normally expressed in neural crest or promyelinating Schwann cells, including Igf $2 b p 1$, Brn2/Pou $3 f 2$, and Tbx2 (Jaegle et al., 2003; Buchstaller et al., 2004). However, most immature Schwann cell genes, such as Sox2, Id2, Egr1, and $\mathrm{Ngfr} / p 75$, and the promyelinating Schwann cell gene Scip/Pou3f1 were not significantly changed by qRT-PCR analysis (Fig. $4 C$; data not shown). Interestingly, $\operatorname{Ig} f 2 b p 3$ was also upregulated in Eed cKO nerves and both Igf $2 b p 1$ and $I g f 2 b p 3$ are strongly associated with various types of cancers (Bell et al., 2013), including Schwann cell-derived malignant peripheral nerve sheath tumors (MPNSTs) associated with neurofibromatosis 1 (Miller et al., 2009). Two recent studies have reported inactivating mutations of PRC2 components (EED or SUZ12) in significant number of MPNST patient samples (De Raedt et al., 2014; Lee et al., 2014). 
A

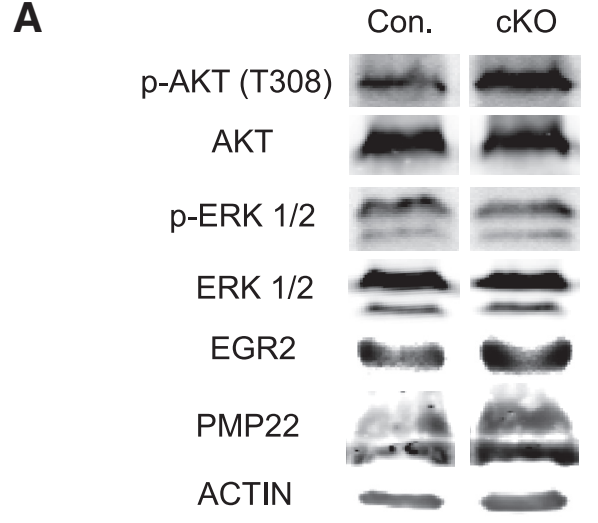

B

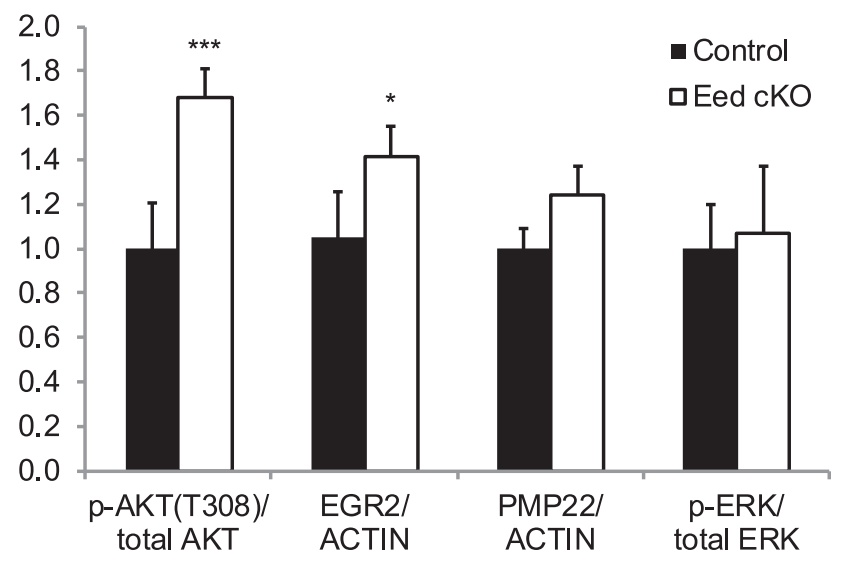

Figure 5. Increased activation of Akt in Eed cKO nerves. Western blot analysis of lysates from control and Eed CKO sciatic nerves using indicated antibodies. A, Blots of 2 month nerves for p-AKT/AKT and blots of 4 month nerves for p-ERK/ERK, EGR2/actin, and PMP22/actin. Lanes of control and Eed CKO samples were taken from the same image of the same membrane. $\boldsymbol{B}$, Quantification of Western blot. p-Akt/Akt; $n=7$ per genotype ( 1 month, $n=3$ per genotype; 2 month, $n=4$ per genotype). p-ERK/ERK, EGR2/actin, and PMP22/actin; 4 month, $n=4$ per genotype. Data: mean \pm SD; ${ }^{* * *} p<0.00001,{ }^{*} p<0.05$.

Genes that are commonly upregulated in PRC2-deficient MPNSTs and Eed cKO nerves include Zicl, Nkd2, Sh3gl2, Dmrta2, Astn1, and Grik1 (Fig. 4B; data not shown).

Increased activation of PI3K/Akt signaling in Eed-deficient peripheral nerves

Myelin thickness is regulated by PI3K/Akt signaling activated by axonal membrane-bound neuregulin 1 (NRG1) isoform III (Michailov et al., 2004; Taveggia et al., 2005; Goebbels et al., 2012). The Eed cKO mice bear several morphological features in common with mice in which there is a Schwann cell-specific deletion of Pten, a gene encoding a negative regulator of Akt signaling (Goebbels et al., 2012). Therefore, we investigated the possibility that Eed ablation can increase this signaling cascade. To this end, we quantified the activation of Akt by measuring phosphorylation at threonine 308, which is directly regulated by PDK1, a downstream kinase of PI3K (Alessi et al., 1997). Although the total Akt level was similar in the two groups, the level of phosphorylated Akt was significantly increased in Eed cKO nerves (Fig. $5 A, B$ ). Importantly, increased phosphorylated Akt (p-Akt) was observed at the beginning of the phenotype progression ( 2 months). Our expression profiling did not show any changes in mRNA or protein levels of Pten, however (Fig. 4A; data not shown).
Activation of ERK1/2 is required for an early stage of myelination (Newbern et al., 2011), but recent studies have also shown that activation of the MEK/ERK cascade can increase myelin thickness (Ishii et al., 2013; Sheean et al., 2014). To test whether the ERK pathway was affected by Eed ablation, we examined sciatic nerves at a midpoint of phenotype progression (4 months), and did not find a statistically significant change in ERK1/2 phosphorylation.

\section{Genome-wide identification of $\mathrm{H} 3 \mathrm{~K} 27 \mathrm{me} 3$-bound genes}

In contrast to active histone modifications (e.g., $\mathrm{H} 3 \mathrm{~K} 4 \mathrm{me} 3$ or $\mathrm{H} 3 \mathrm{~K} 27$ acetylation) that are restricted to focal regions of gene regulatory elements, such as promoters and enhancers, H3K27me3-associated regions are often larger than $10 \mathrm{~kb}$, spanning entire gene bodies and their promoters, as well as focal modifications around transcription start sites (Barski et al., 2007; Mikkelsen et al., 2007; Zhao et al., 2007). Using ChIP-seq analysis of adult wild-type nerves, we determined whether activated genes in the Eed cKO nerves were associated with $\mathrm{H} 3 \mathrm{~K} 27$ methylation in wild-type nerve. We identified 2238 genes with internal $\mathrm{H} 3 \mathrm{~K} 27 \mathrm{me} 3$ peaks and/or a $3 \mathrm{~kb}$ window upstream of the transcription start site. We further identified 32 genes that were both derepressed in Eed-deficient nerves and bound by H3K27me3 in wild-type nerves (Fig. 6C). Such genes include Pax6, Isl1, Shh, Brn2/Pou3f2, Foxg1, and Zic1, which are broadly associated with H3K27me3 (Fig. 6A). In addition, H3K27me3 occupied promoters (but not gene bodies) of some genes, including $\operatorname{Ig} f b p 2$, Igf $2 b p 1$, $\operatorname{Igf} 2 b p 3$, and Gata6. Several of these genes were functionally related to neuronal differentiation, mainly as transcriptional regulators (Isl1, Foxg1, Foxs1, and Pax6). ChIP-qPCR analysis revealed significant reduction of $\mathrm{H} 3 \mathrm{~K} 27 \mathrm{me} 3$ at genes that were derepressed in Eed cKO nerves (Fig. 6B). The residual $\mathrm{H} 3 \mathrm{~K} 27 \mathrm{me} 3-\mathrm{ChIP}$ signal is likely due to residual H3K27me3 in Schwann cells as shown by the immunohistochemistry analysis (Fig. 1B).

To determine whether some of these genes are repressed by H3K27me3 in early Schwann cell development, we compared our data with data from a recent analysis of $\mathrm{H} 3 \mathrm{~K} 27 \mathrm{me} 3$ distribution in human neural crest cells (Rada-Iglesias et al., 2012). $\mathrm{H} 3 \mathrm{~K} 27 \mathrm{me} 3$ is established at 15 of the 32 genes in neural crest cells, including many of the neuronal differentiation genes, suggesting that the derepression of neuronal genes in the Eed cKO nerves reflects a reversal of $\mathrm{H} 3 \mathrm{~K} 27 \mathrm{me} 3$-mediated repression established early in the Schwann cell lineage. In contrast, Emb, Foxs1, and Igf $2 b p 1$ are expressed in neural crest and become repressed during Schwann cell development (Buchstaller et al., 2004; Heglind et al., 2005). Accordingly, ChIP-seq data of neural crest cells show the absence of $\mathrm{H} 3 \mathrm{~K} 27 \mathrm{me} 3$ at these genes and our data indicate repression of such genes is at least partially dependent on the action of EED in the PRC2 complex.

\section{IGFBP2 enhances Akt activation in Schwann cells}

Since there is activation of Akt phosphorylation after nerve injury (Yamazaki et al., 2009; Sun et al., 2013), we reasoned that one of the nerve-injury genes that are also induced in the Eed cKO may be responsible for increased Akt phosphorylation. Igfbp2 is induced in response to peripheral nerve injury (Arthur-Farraj et al., 2012), and IGFBP2 increases Akt signaling in other tissues (DeMambro et al., 2012; Shen et al., 2012; Sharples et al., 2013; Xi et al., 2014). Therefore, we tested the involvement of IGFBP2 in Akt activation of Schwann cells. Treatment with Igfbp2 siRNA resulted in a substantial reduction of the basal level of phosphorylated Akt in RT4 Schwann cells (Fig. $7 A, B$ ). Because the basal 


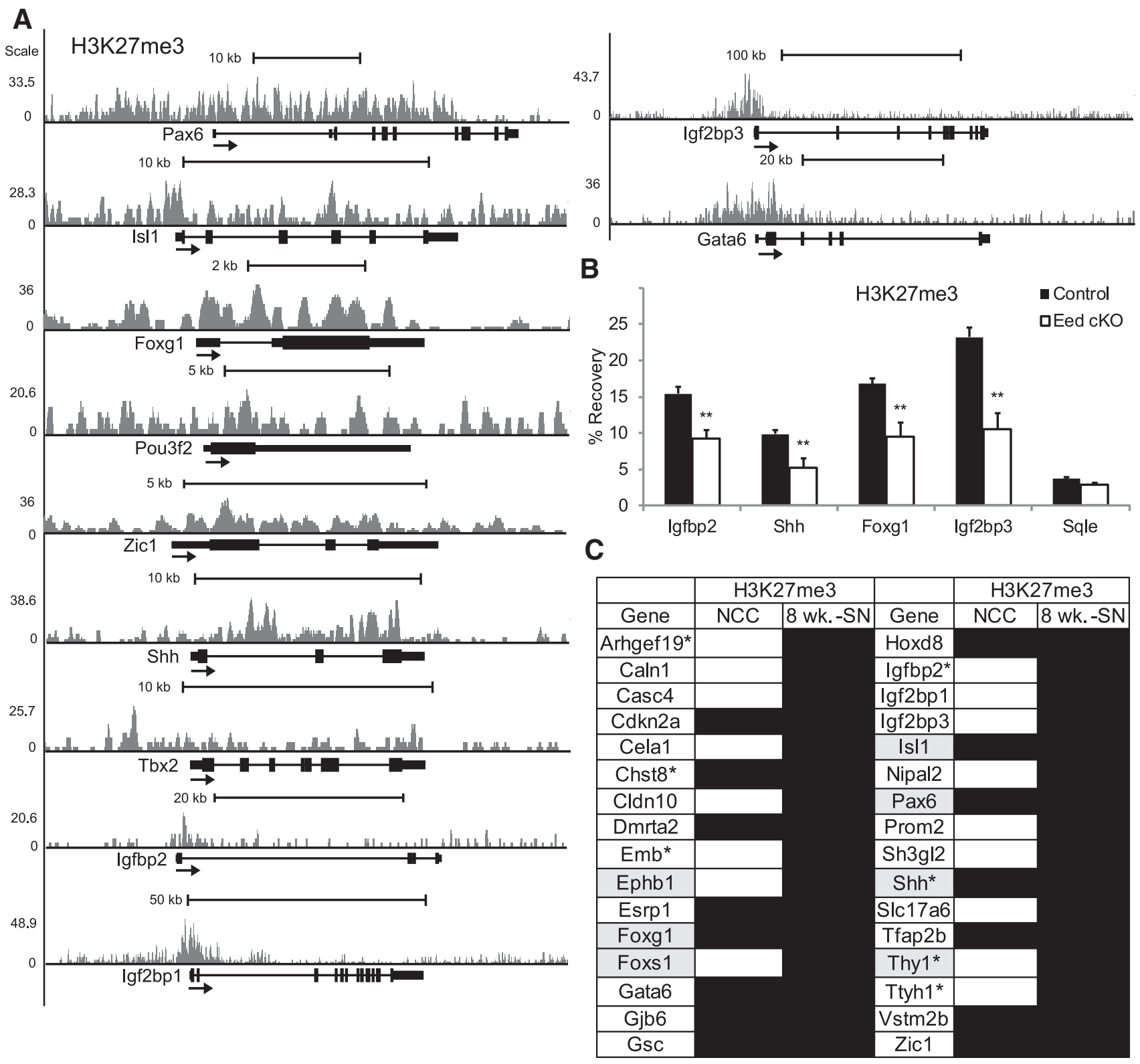

Figure 6. Identification of H3K27me3-bound genes. $A$, ChIP-seq analysis was performed to identify H3K27me3-bound genes in sciatic nerves of 8-week-0ld wild-type mice. Transcription start site is located on the left end of gene. Each gene shown has $\geq 1$ peaks of H3K27me3 as determined by HOMER analysis of ChIP-seq data relative to input chromatin. $\boldsymbol{B}$, ChIP-qPCR analysis was performed to show reduction of H3K27me3 in 1 month Eed cKO sciatic nerves compared with control. Data: mean $\pm S D ; * *<0.005 ; n=3$ per genotype. An actively transcribed gene, squalene epoxidase (Sqle), in Schwann cells has a low H3K27me3 occupancy. C, List of genes that are derepressed in Eed cKO nerves ( $>1.5$-fold) and occupied by H3K27me3 in wild-type sciatic nerves (8 wk.-SN). Black, gray fillings, and asterisks indicate H3K27me3 occupancy, neuronal differentiation genes, and injury-response genes, respectively. H3K27me3-bound genes in human neural crest cells (NCC; Rada-Iglesias et al., 2012) were annotated based on the enrichment of peaks (peak score, $>20$ ) within the genes or a $3 \mathrm{~kb}$ window upstream of the transcription start site .

p-Akt level is very low in primary RSCs, we stimulated RSCs with NRG1 and found that NRG1-induced Akt phosphorylation was reduced, albeit modestly, by Igfbp2 siRNA. Therefore, IGFBP2 promotes Akt phosphorylation in Schwann cells as shown previously in other cell types.

\section{Discussion}

Previous studies have demonstrated that PRC2-mediated regulation of transcriptional programs is critical for cellular differentiation and function in many cell types. Surprisingly, our data indicate that EED activity is not essential for Schwann cell differentiation and myelination in the early postnatal period; however, loss of Eed results in hypermyelination of smaller-diameter axons and focal myelin infolding. The hypermyelination phenotype has been observed in mutant mice with hyperactive PI3K/Akt or MAPK signaling (Goebbels et al., 2012; Ishii et al., 2013; Sheean et al., 2014), and Eed cKO mice display a similar, albeit milder, hypermyelination consistent with an elevated level of phosphorylated Akt. Our data reveal that an epigenomic pathway mediated by H3K27me3 constitutes a novel determinant of mature myelin thickness.

We have surveyed a number of genes encoding molecular components of Akt signaling, including several genes that have hypermyelination phenotypes when disrupted, such as Ddit4, Vimentin, and Sgk1, as well as Pten (Triolo et al., 2012; Noseda et al., 2013; Heller et al., 2014), but their mRNAs are largely unaf- 
A
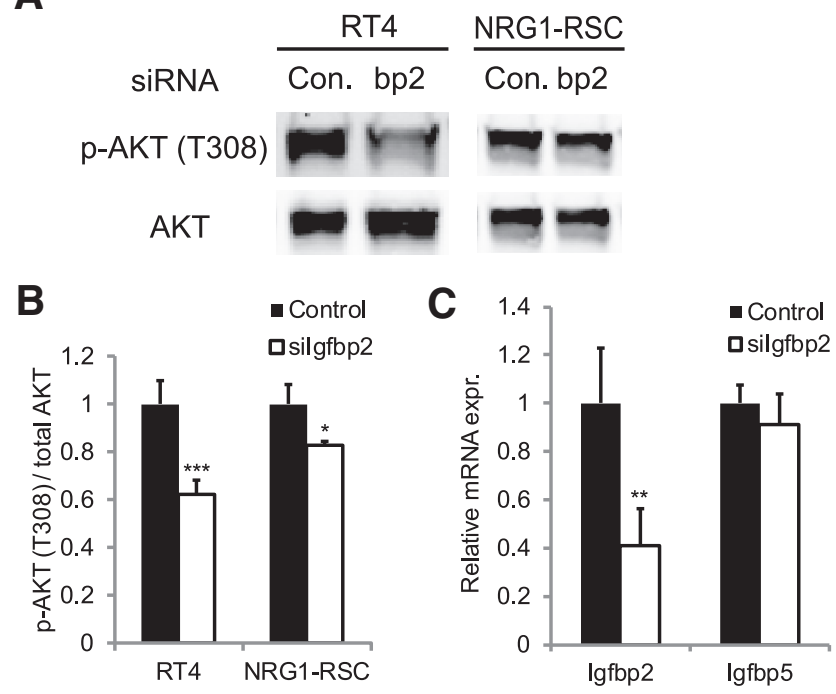

Figure 7. siRNA-mediated lgfbp2 reduction in Schwann cells reduces Akt phosphorylation. $A$, Lysates from control and lgfbp2 siRNA-treated RT4 and RSCs were subjected to Western blot. Overnight serum-starved RSCs were stimulated with neuregulin for $20 \mathrm{~min}$ before protein isolation. B, Quantification of Western blot. p-Akt/Akt; RT4 and RSCs, $n=6$ and $n=3$ per each condition, respectively. C, qRT-PCR analysis was used to identify the siRNA-mediated knockdown level in RT4. Values normalized with $18 \mathrm{~S}$ rRNA. $n=3$ per each condition. Expression of an adjacent gene, Igfbp5, was not affected by the siRNA treatment. Data: mean $\pm S D ;{ }^{*} p<0.05$, ${ }^{* *} p<0.005,{ }^{* * *} p<0.00005$.

fected in Eed cKO nerves. In addition, recent studies demonstrated that dysregulation of the $\alpha 6 \beta 4$ integrin signaling that drives phosphorylation of NDRG1 results in hypermyelination and myelin folding (Nodari et al., 2008; Heller et al., 2014). However, we found no significant changes in either NDRG1 phosphorylation (data not shown) or phosphorylation of focal adhesion kinase, a ubiquitously expressed cytoskeletal scaffolding protein involved in cytoskeletal regulation and myelination (Grove and Brophy, 2014). Instead, we identified Igfbp2, a gene that is normally activated after nerve injury (Arthur-Farraj et al., 2012), among derepressed genes and showed its ability to enhance Akt signaling in Schwann cells. Igfbp2 is expressed in neural crest cells, but becomes repressed in embryonic Schwann cell development (Buchstaller et al., 2004), and our data indicate that this repression is dependent on $\mathrm{H} 3 \mathrm{~K} 27$ methylation mediated by PRC2.

Aside from Igfbp2, derepressed genes of Eed cKO nerves include several genes that are activated upon nerve injury (ArthurFarraj et al., 2012). Importantly, the induction of these genes is not accompanied by induction of $c$-Jun and the broader c-JUNdependent gene network. The presence of $\mathrm{H} 3 \mathrm{~K} 27 \mathrm{me} 3$ at many of these genes in mature nerve, as well as reduction of methylation at Shh and Igfbp2 (Fig. 6B) in Eed cKO nerves, indicates that their derepression is primarily mediated by PRC2 inactivation. Furthermore, their derepression implies that H3K27 demethylation may be involved in the activation in response to injury. A recent study showed that the expression of the histone H3K27 demethylase JMJD3 increases after peripheral nerve injury and its upregulation is correlated to the activation of $C d k n 2 a$ locus (Gomez-Sanchez et al., 2013). Overall, our data would suggest H3K27 methylation prevents inappropriate expression of injury genes and that $\mathrm{H} 3 \mathrm{~K} 27$ demethylases are likely involved in the activation of a subset of injury-response genes. Interestingly, we have recently found induction of $\mathrm{H} 3 \mathrm{~K} 27$ acetylation at several enhancers surrounding injury-response genes after peripheral nerve injury (Hung et al., 2015).

Our studies also revealed that Eed deficiency affects nmSCs in Remak bundles. Remak bundle fragmentation has been identified as a characteristic feature of mouse models of neurofibromatosis type I (Zhu et al., 2002; Ling et al., 2005; Wu et al., 2008; Zheng et al., 2008; Mayes et al., 2011), and also was observed in the desert hedgehog knock-out (Sharghi-Namini et al., 2006). The outcomes of our structural analyses suggest that abnormal separation of $\mathrm{nmSC}$ processes is a main underlying feature of the phenotype. Changes in nmSC morphology would presumably impair axon protection as indicated by retracted $\mathrm{nmSC}$ processes that are free from axons and a decreased number of unmyelinated axons. Interestingly, a previous study using shRNA-mediated suppression of Ezh2 in Schwann cells in culture showed shortening of cellular processes (Heinen et al., 2012), and we speculate that the Remak bundle disruption may be due to a similar phenomenon. Our data indicate a crucial function of the PRC2-mediated maintenance of peripheral nerves, given that removal of the EED subunit results in progressive hypermyelination and abnormalities affecting both myelinated fibers and Remak bundles.

Schwarz et al. recently reported that conditional inactivation of Ezh2, the catalytic subunit of PRC2, in premigratory neural crest cells in vivo revealed no apparent defects in the formation of peripheral nerves (Schwarz et al., 2014). These outcomes, together with our analysis of Eed cKO nerves, suggest that PRC2 is not required for early events in Schwann cell development. Since only a small fraction of genes enriched with $\mathrm{H} 3 \mathrm{~K} 27 \mathrm{me} 3$ are derepressed, H3K27me3 formation may be redundant with other repressive mechanisms. For example, this might be due to cooccupancy of $\mathrm{H} 3 \mathrm{~K} 9 \mathrm{me} 3$ identified by our ChIP-chip analysis at genes such as Sox2 and Scip/Oct6 (data not shown). Alternatively, persistent repression may be due to the action of histone deacetylases (Chen et al., 2011; Jacob et al., 2011) within repressive chromatin remodeling complexes, such as the NuRD complex (Hung et al., 2012), and/or histone modification-independent repression of genes. The role of DNA methylation in Schwann cell development has recently been described in repression of myelin gene expression before myelination since DNA demethylation is associated with their activation (Varela-Rey et al., 2014), but its repressive role has so far not been implicated in genes being downregulated during myelination.

Derepression of transcriptional regulators of neuronal differentiation indicates that PRC2 activity in Schwann cells represses several neuronal transcription factors. H3K27me3-mediated repression of neuronal program is also found to be deregulated in tissue-specific PRC2 mutants of skin and heart development and in Eed mutant ES cells (Boyer et al., 2006; Ezhkova et al., 2011; He et al., 2012), reflecting a distinct role of PRC2 in non-neural tissues that takes place at an early stage of the development. These neuronal genes appear to be repressed early in Schwann cell development, since the ChIP-seq data of neural crest cells reveal the H3K27me3 marks at several genes that we identified in mature nerves, including Pax6, Shh, Foxg1, and Isl1 (Rada-Iglesias et al., 2012; Fig. 6C). Furthermore, our data also indicate that the repression is reversible upon PRC2 inactivation at immature Schwann cell stage. However, although significantly induced compared with control nerves (Fig. 4C), the transcript levels of neuronal transcription factors in Eed cKO nerves are probably not fully expressed due to lack of tissue-specific transcriptional cues that are required for full activation. Such low levels of derepression may not be sufficient to alter Schwann cell fate or the myelination program. 
Ezh2-suppressed Schwann cells in culture showed a marked decrease in myelin gene expression accompanied with a significant increase of negative regulators $p 57$ and Hes 5 (Heinen et al., 2012). We also observed a moderate decrease of several myelin genes (Fig. 4A), but the transcript levels of $p 57$ and Hes 5 were unaffected in our qRT-PCR analysis (data not shown). The apparent discrepancy may be due to potential compensation by EZH1, which can substitute as a histone methylase for EZH2. In addition, there is a difference in transcriptional regulation of these genes between proliferating Schwann cells in culture and our studies of myelinated nerves where proliferation has ceased.

In several tissues, PRC2 mutation causes reduced cell proliferation associated with the developmental abnormalities of the tissues (Ezhkova et al., 2009; Juan et al., 2011; He et al., 2012). Ezh2-suppressed Schwann cells in culture also showed a decreased number of proliferative cells (Heinen et al., 2012). However, Eed cKO nerves display similar numbers of nmSC nuclei (Fig. 3E) compared with control nerves, suggesting that proliferation is normal. Additionally, no proliferative defects were observed also in peripheral nerves differentiated from neural crest cells with a deletion of Ezh2 (Schwarz et al., 2014), suggesting that PRC2 inactivation does not critically impair Schwann cell growth in peripheral nerve development. However, two recent studies have shown that a significant number of Schwann cell-derived MPNSTs associated with neurofibromatosis 1 have mutations in EED and another PRC2 component, SUZ12, leading to loss of H3K27me3 (De Raedt et al., 2014; Lee et al., 2014). The cooccurrence of PRC2 alterations with NF1 and CDKN2A mutations indicate that loss of $\mathrm{H} 3 \mathrm{~K} 27 \mathrm{me} 3$ plays an important role in promoting Ras-dependent growth of MPNSTs. We compared genes deregulated in PRC2-deficient MPNSTs with our dataset to identify genes whose expression may be PRC2 dependent in both development and MPNST formation. Similar to what was observed, we also observed deregulation of homeobox transcriptional regulators as well as components of IGF signaling pathways.

\section{References}

Aldiri I, Vetter ML (2012) PRC2 during vertebrate organogenesis: a complex in transition. Dev Biol 367:91-99. CrossRef Medline

Alessi DR, James SR, Downes CP, Holmes AB, Gaffney PR, Reese CB, Cohen $P$ (1997) Characterization of a 3-phosphoinositide-dependent protein kinase which phosphorylates and activates protein kinase Balpha. Curr Biol 7:261-269. CrossRef Medline

Arthur-Farraj PJ, Latouche M, Wilton DK, Quintes S, Chabrol E, Banerjee A, Woodhoo A, Jenkins B, Rahman M, Turmaine M, Wicher GK, Mitter R, Greensmith L, Behrens A, Raivich G, Mirsky R, Jessen KR (2012) c-Jun reprograms Schwann cells of injured nerves to generate a repair cell essential for regeneration. Neuron 75:633-647. CrossRef Medline

Barski A, Cuddapah S, Cui K, Roh TY, Schones DE, Wang Z, Wei G, Chepelev I, Zhao K (2007) High-resolution profiling of histone methylations in the human genome. Cell 129:823-837. CrossRef Medline

Bell JL, Wächter K, Mühleck B, Pazaitis N, Köhn M, Lederer M, Hüttelmaier S (2013) Insulin-like growth factor 2 mRNA-binding proteins (IGF2BPs): post-transcriptional drivers of cancer progression? Cell Mol Life Sci 70:26572675. CrossRef Medline

Boyer LA, Plath K, Zeitlinger J, Brambrink T, Medeiros LA, Lee TI, Levine SS, Wernig M, Tajonar A, Ray MK, Bell GW, Otte AP, Vidal M, Gifford DK, Young RA, Jaenisch R (2006) Polycomb complexes repress developmental regulators in murine embryonic stem cells. Nature 441:349-353. CrossRef Medline

Buchstaller J, Sommer L, Bodmer M, Hoffmann R, Suter U, Mantei N (2004) Efficient isolation and gene expression profiling of small numbers of neural crest stem cells and developing Schwann cells. J Neurosci 24:23572365. CrossRef Medline

Chen H, Gu X, Su IH, Bottino R, Contreras JL, Tarakhovsky A, Kim SK (2009) Polycomb protein Ezh2 regulates pancreatic beta-cell Ink4a/Arf expression and regeneration in diabetes mellitus. Genes Dev 23:975-985. CrossRef Medline

Chen Y, Wang H, Yoon SO, Xu X, Hottiger MO, Svaren J, Nave KA, Kim HA, Olson EN, Lu QR (2011) HDAC-mediated deacetylation of NF- $\kappa \mathrm{B}$ is critical for Schwann cell myelination. Nat Neurosci 14:437-441. CrossRef Medline

Chuang PT, McMahon AP (1999) Vertebrate Hedgehog signalling modulated by induction of a Hedgehog-binding protein. Nature 397:617-621. CrossRef Medline

Decker L, Desmarquet-Trin-Dinh C, Taillebourg E, Ghislain J, Vallat JM, Charnay P (2006) Peripheral myelin maintenance is a dynamic process requiring constant Krox20 expression. J Neurosci 26:9771-9779. CrossRef Medline

DeMambro VE, Maile L, Wai C, Kawai M, Cascella T, Rosen CJ, Clemmons D (2012) Insulin-like growth factor-binding protein-2 is required for osteoclast differentiation. J Bone Miner Res 27:390-400. CrossRef Medline

De Raedt T, Beert E, Pasmant E, Luscan A, Brems H, Ortonne N, Helin K, Hornick JL, Mautner V, Kehrer-Sawatzki H, Clapp W, Bradner J, Vidaud M, Upadhyaya M, Legius E, Cichowski K (2014) PRC2 loss amplifies Ras-driven transcription and confers sensitivity to BRD4-based therapies. Nature 514:247-251. CrossRef Medline

Du P, Kibbe WA, Lin SM (2008) lumi: a pipeline for processing Illumina microarray. Bioinformatics 24:1547-1548. CrossRef Medline

Egelhofer TA, Minoda A, Klugman S, Lee K, Kolasinska-Zwierz P, Alekseyenko AA, Cheung MS, Day DS, Gadel S, Gorchakov AA, Gu T, Kharchenko PV, Kuan S, Latorre I, Linder-Basso D, Luu Y, Ngo Q, Perry M, Rechtsteiner A, Riddle NC, et al. (2011) An assessment of histonemodification antibody quality. Nat Struct Mol Biol 18:91-93. CrossRef Medline

Endoh M, Endo TA, Endoh T, Fujimura Y, Ohara O, Toyoda T, Otte AP, Okano M, Brockdorff N, Vidal M, Koseki H (2008) Polycomb group proteins Ring1A/B are functionally linked to the core transcriptional regulatory circuitry to maintain ES cell identity. Development 135:15131524. CrossRef Medline

Ezhkova E, Pasolli HA, Parker JS, Stokes N, Su IH, Hannon G, Tarakhovsky A, Fuchs E (2009) Ezh2 orchestrates gene expression for the stepwise differentiation of tissue-specific stem cells. Cell 136:1122-1135. CrossRef Medline

Ezhkova E, Lien WH, Stokes N, Pasolli HA, Silva JM, Fuchs E (2011) EZH1 and EZH2 cogovern histone H3K27 trimethylation and are essential for hair follicle homeostasis and wound repair. Genes Dev 25:485-498. CrossRef Medline

Faust C, Schumacher A, Holdener B, Magnuson T (1995) The eed mutation disrupts anterior mesoderm production in mice. Development 121:273285. Medline

Feltri ML, D’Antonio M, Previtali S, Fasolini M, Messing A, Wrabetz L (1999) P0-Cre transgenic mice for inactivation of adhesion molecules in Schwann cells. Ann N Y Acad Sci 883:116-123. CrossRef Medline

Goebbels S, Oltrogge JH, Wolfer S, Wieser GL, Nientiedt T, Pieper A, Ruhwedel T, Groszer M, Sereda MW, Nave KA (2012) Genetic disruption of Pten in a novel mouse model of tomaculous neuropathy. EMBO Mol Med 4:486-499. CrossRef Medline

Gomez-Sanchez JA, Gomis-Coloma C, Morenilla-Palao C, Peiro G, Serra E, Serrano M, Cabedo H (2013) Epigenetic induction of the Ink4a/Arf locus prevents Schwann cell overproliferation during nerve regeneration and after tumorigenic challenge. Brain 136:2262-2278. CrossRef Medline

Grove M, Brophy PJ (2014) FAK is required for Schwann cell spreading on immature basal lamina to coordinate the radial sorting of peripheral axons with myelination. J Neurosci 34:13422-13434. CrossRef Medline

Hansen KH, Bracken AP, Pasini D, Dietrich N, Gehani SS, Monrad A, Rappsilber J, Lerdrup M, Helin K (2008) A model for transmission of the H3K27me3 epigenetic mark. Nat Cell Biol 10:1291-1300. CrossRef Medline

Hashimoto M, Ishii K, Nakamura Y, Watabe K, Kohsaka S, Akazawa C (2008) Neuroprotective effect of sonic hedgehog up-regulated in Schwann cells following sciatic nerve injury. J Neurochem 107:918-927. Medline

He A, Ma Q, Cao J, von Gise A, Zhou P, Xie H, Zhang B, Hsing M, Christodoulou DC, Cahan P, Daley GQ, Kong SW, Orkin SH, Seidman CE, Seidman JG, Pu WT (2012) Polycomb repressive complex 2 regulates normal development of the mouse heart. Circ Res 110:406-415. CrossRef Medline 
Heglind M, Cederberg A, Aquino J, Lucas G, Ernfors P, Enerbäck S (2005) Lack of the central nervous system- and neural crest-expressed forkhead gene Foxs1 affects motor function and body weight. Mol Cell Biol 25: 5616-5625. CrossRef Medline

Heinen A, Tzekova N, Graffmann N, Torres KJ, Uhrberg M, Hartung HP, Küry P (2012) Histone methyltransferase enhancer of zeste homolog 2 regulates Schwann cell differentiation. Glia 60:1696-1708. CrossRef Medline

Heinz S, Benner C, Spann N, Bertolino E, Lin YC, Laslo P, Cheng JX, Murre C, Singh H, Glass CK (2010) Simple combinations of lineage-determining transcription factors prime cis-regulatory elements required for macrophage and B cell identities. Mol Cell 38:576-589. CrossRef Medline

Heller BA, Ghidinelli M, Voelkl J, Einheber S, Smith R, Grund E, Morahan G, Chandler D, Kalaydjieva L, Giancotti F, King RH, Fejes-Toth AN, FejesToth G, Feltri ML, Lang F, Salzer JL (2014) Functionally distinct PI 3-kinase pathways regulate myelination in the peripheral nervous system. J Cell Biol 204:1219-1236. CrossRef Medline

Huang da W, Sherman BT, Lempicki RA (2009a) Bioinformatics enrichment tools: paths toward the comprehensive functional analysis of large gene lists. Nucleic Acids Res 37:1-13. CrossRef Medline

Huang da W, Sherman BT, Lempicki RA (2009b) Systematic and integrative analysis of large gene lists using DAVID bioinformatics resources. Nat Protoc 4:44-57. CrossRef Medline

Hung H, Kohnken R, Svaren J (2012) The nucleosome remodeling and deacetylase chromatin remodeling (NuRD) complex is required for peripheral nerve myelination. J Neurosci 32:1517-1527. CrossRef Medline

Hung HA, Sun G, Keles S, Svaren J (2015) Dynamic regulation of Schwann cell enhancers after peripheral nerve injury. J Biol Chem 290:6937-6950. CrossRef Medline

Ishii A, Furusho M, Bansal R (2013) Sustained activation of ERK1/2 MAPK in oligodendrocytes and Schwann cells enhances myelin growth and stimulates oligodendrocyte progenitor expansion. J Neurosci 33:175-186. CrossRef Medline

Jacob C, Christen CN, Pereira JA, Somandin C, Baggiolini A, Lötscher P, Ozçelik M, Tricaud N, Meijer D, Yamaguchi T, Matthias P, Suter U (2011) HDAC1 and HDAC2 control the transcriptional program of myelination and the survival of Schwann cells. Nat Neurosci 14:429-436. CrossRef Medline

Jaegle M, Ghazvini M, Mandemakers W, Piirsoo M, Driegen S, Levavasseur F, Raghoenath S, Grosveld F, Meijer D (2003) The POU proteins Brn-2 and Oct-6 share important functions in Schwann cell development. Genes Dev 17:1380-1391. CrossRef Medline

Jang SW, LeBlanc SE, Roopra A, Wrabetz L, Svaren J (2006) In vivo detection of Egr2 binding to target genes during peripheral nerve myelination. J Neurochem 98:1678-1687. CrossRef Medline

Jessen KR, Mirsky R (2008) Negative regulation of myelination: relevance for development, injury, and demyelinating disease. Glia 56:1552-1565. CrossRef Medline

Juan AH, Derfoul A, Feng X, Ryall JG, Dell'Orso S, Pasut A, Zare H, Simone JM, Rudnicki MA, Sartorelli V (2011) Polycomb EZH2 controls selfrenewal and safeguards the transcriptional identity of skeletal muscle stem cells. Genes Dev 25:789-794. CrossRef Medline

Kenney AM, Rowitch DH (2000) Sonic hedgehog promotes G(1) cyclin expression and sustained cell cycle progression in mammalian neuronal precursors. Mol Cell Biol 20:9055-9067. CrossRef Medline

Kim Y, Remacle AG, Chernov AV, Liu H, Shubayev I, Lai C, Dolkas J, Shiryaev SA, Golubkov VS, Mizisin AP, Strongin AY, Shubayev VI (2012) The MMP-9/TIMP-1 axis controls the status of differentiation and function of myelin-forming Schwann cells in nerve regeneration. PLoS One 7:e33664. CrossRef Medline

Ku M, Koche RP, Rheinbay E, Mendenhall EM, Endoh M, Mikkelsen TS, Presser A, Nusbaum C, Xie X, Chi AS, Adli M, KasifS, Ptaszek LM, Cowan CA, Lander ES, Koseki H, Bernstein BE (2008) Genomewide analysis of PRC1 and PRC2 occupancy identifies two classes of bivalent domains. PLoS Genet 4:e1000242. CrossRef Medline

Lanzuolo C, Lo Sardo F, Diamantini A, Orlando V (2011) PcG complexes set the stage for epigenetic inheritance of gene silencing in early $S$ phase before replication. PLoS Genet 7:e1002370. CrossRef Medline

Le N, Nagarajan R, Wang JY, Araki T, Schmidt RE, Milbrandt J (2005) Analysis of congenital hypomyelinating Egr2Lo/Lo nerves identifies Sox2 as an inhibitor of Schwann cell differentiation and myelination. Proc Natl Acad Sci U S A 102:2596-2601. CrossRef Medline
Lee W, Teckie S, Wiesner T, Ran L, Prieto Granada CN, Lin M, Zhu S, Cao Z, Liang Y, Sboner A, Tap WD, Fletcher JA, Huberman KH, Qin LX, Viale A, Singer S, Zheng D, Berger MF, Chen Y, Antonescu CR, et al. (2014) PRC2 is recurrently inactivated through EED or SUZ12 loss in malignant peripheral nerve sheath tumors. Nat Genet 46:1227-1232. CrossRef Medline

Leung C, Lingbeek M, Shakhova O, Liu J, Tanger E, Saremaslani P, Van Lohuizen M, Marino S (2004) Bmil is essential for cerebellar development and is overexpressed in human medulloblastomas. Nature 428:337341. CrossRef Medline

Ling BC, Wu J, Miller SJ, Monk KR, Shamekh R, Rizvi TA, Decourten-Myers G, Vogel KS, DeClue JE, Ratner N (2005) Role for the epidermal growth factor receptor in neurofibromatosis-related peripheral nerve tumorigenesis. Cancer Cell 7:65-75. CrossRef Medline

Margueron R, Justin N, Ohno K, Sharpe ML, Son J, Drury WJ 3rd, Voigt P, Martin SR, Taylor WR, De Marco V, Pirrotta V, Reinberg D, Gamblin SJ (2009) Role of the polycomb protein EED in the propagation of repressive histone marks. Nature 461:762-767. CrossRef Medline

Mayes DA, Rizvi TA, Cancelas JA, Kolasinski NT, Ciraolo GM, StemmerRachamimov AO, Ratner N (2011) Perinatal or adult Nf1 inactivation using tamoxifen-inducible PlpCre each cause neurofibroma formation. Cancer Res 71:4675-4685. CrossRef Medline

Michailov GV, Sereda MW, Brinkmann BG, Fischer TM, Haug B, Birchmeier C, Role L, Lai C, Schwab MH, Nave KA (2004) Axonal neuregulin-1 regulates myelin sheath thickness. Science 304:700-703. CrossRef Medline

Mikkelsen TS, Ku M, Jaffe DB, Issac B, Lieberman E, Giannoukos G, Alvarez P, Brockman W, Kim TK, Koche RP, Lee W, Mendenhall E, O'Donovan A, Presser A, Russ C, Xie X, Meissner A, Wernig M, Jaenisch R, Nusbaum C, et al. (2007) Genome-wide maps of chromatin state in pluripotent and lineage-committed cells. Nature 448:553-560. CrossRef Medline

Miller OJ, Schnedl W, Allen J, Erlanger BF (1974) 5-Methylcytosine localised in mammalian constitutive heterochromatin. Nature 251:636637. CrossRef Medline

Miller SJ, Jessen WJ, Mehta T, Hardiman A, Sites E, Kaiser S, Jegga AG, Li H, Upadhyaya M, Giovannini M, Muir D, Wallace MR, Lopez E, Serra E, Nielsen GP, Lazaro C, Stemmer-Rachamimov A, Page G, Aronow BJ, Ratner N (2009) Integrative genomic analyses of neurofibromatosis tumours identify SOX9 as a biomarker and survival gene. EMBO Mol Med 1:236-248. CrossRef Medline

Montelius A, Marmigère F, Baudet C, Aquino JB, Enerbäck S, Ernfors P (2007) Emergence of the sensory nervous system as defined by Foxs1 expression. Differentiation 75:404-417. CrossRef Medline

Montgomery ND, Yee D, Chen A, Kalantry S, Chamberlain SJ, Otte AP, Magnuson T (2005) The murine polycomb group protein Eed is required for global histone H3 lysine-27 methylation. Curr Biol 15:942-947. CrossRef Medline

Montgomery ND, Yee D, Montgomery SA, Magnuson T (2007) Molecular and functional mapping of EED motifs required for PRC2-dependent histone methylation. J Mol Biol 374:1145-1157. CrossRef Medline

Newbern JM, Li X, Shoemaker SE, Zhou J, Zhong J, Wu Y, Bonder D, Hollenback S, Coppola G, Geschwind DH, Landreth GE, Snider WD (2011) Specific functions for ERK/MAPK signaling during PNS development. Neuron 69:91-105. CrossRef Medline

Nodari A, Previtali SC, Dati G, Occhi S, Court FA, Colombelli C, Zambroni D, Dina G, Del Carro U, Campbell KP, Quattrini A, Wrabetz L, Feltri ML (2008) $\alpha 6 \beta 4$ Integrin and dystroglycan cooperate to stabilize the myelin sheath. J Neurosci 28:6714-6719. CrossRef Medline

Noseda R, Belin S, Piguet F, Vaccari I, Scarlino S, Brambilla P, Martinelli Boneschi F, Feltri ML, Wrabetz L, Quattrini A, Feinstein E, Huganir RL, Bolino A (2013) DDIT4/REDD1/RTP801 is a novel negative regulator of Schwann cell myelination. J Neurosci 33:15295-15305. CrossRef Medline

O'Carroll D, Erhardt S, Pagani M, Barton SC, Surani MA, Jenuwein T (2001) The polycomb-group gene Ezh2 is required for early mouse development. Mol Cell Biol 21:4330-4336. CrossRef Medline

Pabst O, Herbrand H, Takuma N, Arnold HH (2000) NKX2 gene expression in neuroectoderm but not in mesendodermally derived structures depends on sonic hedgehog in mouse embryos. Dev Genes Evol 210: 47-50. CrossRef Medline

Pasini D, Bracken AP, Jensen MR, Lazzerini Denchi E, Helin K (2004) Suz12 
is essential for mouse development and for EZH2 histone methyltransferase activity. EMBO J 23:4061-4071. CrossRef Medline

Pasini D, Hansen KH, Christensen J, Agger K, Cloos PA, Helin K (2008) Coordinated regulation of transcriptional repression by the RBP2 H3K4 demethylase and polycomb-repressive complex 2. Genes Dev 22:13451355. CrossRef Medline

Peters AH, Kubicek S, Mechtler K, O'Sullivan RJ, Derijck AA, Perez-Burgos L, Kohlmaier A, Opravil S, Tachibana M, Shinkai Y, Martens JH, Jenuwein T (2003) Partitioning and plasticity of repressive histone methylation states in mammalian chromatin. Mol Cell 12:1577-1589. CrossRef Medline

Rada-Iglesias A, Bajpai R, Prescott S, Brugmann SA, Swigut T, Wysocka J (2012) Epigenomic annotation of enhancers predicts transcriptional regulators of human neural crest. Cell Stem Cell 11:633-648. CrossRef Medline

Rasi K, Hurskainen M, Kallio M, Stavén S, Sormunen R, Heape AM, Avila RL, Kirschner D, Muona A, Tolonen U, Tanila H, Huhtala P, Soininen R, Pihlajaniemi T (2010) Lack of collagen XV impairs peripheral nerve maturation and, when combined with laminin-411 deficiency, leads to basement membrane abnormalities and sensorimotor dysfunction. J Neurosci 30:14490-14501. CrossRef Medline

Schmidt D, Wilson MD, Spyrou C, Brown GD, Hadfield J, Odom DT (2009) ChIP-seq: using high-throughput sequencing to discover protein-DNA interactions. Methods 48:240-248. CrossRef Medline

Schwarz D, Varum S, Zemke M, Schöler A, Baggiolini A, Draganova K, Koseki H, Schübeler D, Sommer L (2014) Ezh2 is required for neural crestderived cartilage and bone formation. Development 141:867-877. CrossRef Medline

Sharghi-Namini S, Turmaine M, Meier C, Sahni V, Umehara F, Jessen KR, Mirsky R (2006) The structural and functional integrity of peripheral nerves depends on the glial-derived signal desert hedgehog. J Neurosci 26:6364-6376. CrossRef Medline

Sharples AP, Al-Shanti N, Hughes DC, Lewis MP, Stewart CE (2013) The role of insulin-like-growth factor binding protein 2 (IGFBP2) and phosphatase and tensin homologue (PTEN) in the regulation of myoblast differentiation and hypertrophy. Growth Horm IGF Res 23:53-61. CrossRef Medline

Sheean ME, McShane E, Cheret C, Walcher J, Müller T, Wulf-Goldenberg A, Hoelper S, Garratt AN, Krüger M, Rajewsky K, Meijer D, Birchmeier W, Lewin GR, Selbach M, Birchmeier C (2014) Activation of MAPK overrides the termination of myelin growth and replaces $\mathrm{Nrg} 1 / \mathrm{ErbB} 3$ signals during Schwann cell development and myelination. Genes Dev 28:290303. CrossRef Medline

Shen X, Liu Y, Hsu YJ, Fujiwara Y, Kim J, Mao X, Yuan GC, Orkin SH (2008) EZH1 mediates methylation on histone $\mathrm{H} 3$ lysine 27 and complements EZH2 in maintaining stem cell identity and executing pluripotency. Mol Cell 32:491-502. CrossRef Medline

Shen X, Xi G, Maile LA, Wai C, Rosen CJ, Clemmons DR (2012) Insulin-like growth factor (IGF) binding protein 2 functions coordinately with receptor protein tyrosine phosphatase $\beta$ and the IGF-I receptor to regulate IGF-I-stimulated signaling. Mol Cell Biol 32:4116-4130. CrossRef Medline

Stock JK, Giadrossi S, Casanova M, Brookes E, Vidal M, Koseki H, Brockdorff N, Fisher AG, Pombo A (2007) Ring1-mediated ubiquitination of H2A restrains poised RNA polymerase II at bivalent genes in mouse ES cells. Nat Cell Biol 9:1428-1435. CrossRef Medline

Sun G, Li Z, Wang X, Tang W, Wei Y (2013) Modulation of MAPK and Akt signaling pathways in proximal segment of injured sciatic nerves. Neurosci Lett 534:205-210. CrossRef Medline

Svaren J, Meijer D (2008) The molecular machinery of myelin gene transcription in Schwann cells. Glia 56:1541-1551. CrossRef Medline
Taveggia C, Zanazzi G, Petrylak A, Yano H, Rosenbluth J, Einheber S, Xu X, Esper RM, Loeb JA, Shrager P, Chao MV, Falls DL, Role L, Salzer JL (2005) Neuregulin-1 type III determines the ensheathment fate of axons. Neuron 47:681-694. CrossRef Medline

Topilko P, Schneider-Maunoury S, Levi G, Baron-Van Evercooren A, Chennoufi AB, Seitanidou T, Babinet C, Charnay P (1994) Krox-20 controls myelination in the peripheral nervous system. Nature 371:796-799. CrossRef Medline

Triolo D, Dina G, Taveggia C, Vaccari I, Porrello E, Rivellini C, Domi T, La Marca R, Cerri F, Bolino A, Quattrini A, Previtali SC (2012) Vimentin regulates peripheral nerve myelination. Development 139:1359-1367. CrossRef Medline

Umlauf D, Goto Y, Feil R (2004) Site-specific analysis of histone methylation and acetylation. Methods Mol Biol 287:99-120. Medline

Varela-Rey M, Iruarrizaga-Lejarreta M, Lozano JJ, Aransay AM, Fernandez AF, Lavin JL, Mósen-Ansorena D, Berdasco M, Turmaine M, Luka Z, Wagner C, Lu SC, Esteller M, Mirsky R, Jessen KR, Fraga MF, MartínezChantar ML, Mato JM, Woodhoo A (2014) S-adenosylmethionine levels regulate the Schwann cell DNA methylome. Neuron 81:1024-1039. CrossRef Medline

Viré E, Brenner C, Deplus R, Blanchon L, Fraga M, Didelot C, Morey L, Van Eynde A, Bernard D, Vanderwinden JM, Bollen M, Esteller M, Di Croce L, de Launoit Y, Fuks F (2006) The Polycomb group protein EZH2 directly controls DNA methylation. Nature 439:871-874. Medline

Vokes SA, Ji H, McCuine S, Tenzen T, Giles S, Zhong S, Longabaugh WJ, Davidson EH, Wong WH, McMahon AP (2007) Genomic characterization of Gli-activator targets in sonic hedgehog-mediated neural patterning. Development 134:1977-1989. CrossRef Medline

Weider M, Küspert M, Bischof M, Vogl MR, Hornig J, Loy K, Kosian T, Müller J, Hillgärtner S, Tamm ER, Metzger D, Wegner M (2012) Chromatin-remodeling factor Brg1 is required for Schwann cell differentiation and myelination. Dev Cell 23:193-201. CrossRef Medline

Wettenhall JM, Smyth GK (2004) limmaGUI: a graphical user interface for linear modeling of microarray data. Bioinformatics 20:3705-3706. CrossRef Medline

Wu J, Williams JP, Rizvi TA, Kordich JJ, Witte D, Meijer D, StemmerRachamimov AO, Cancelas JA, Ratner N (2008) Plexiform and dermal neurofibromas and pigmentation are caused by Nf1 loss in desert hedgehog-expressing cells. Cancer Cell 13:105-116. CrossRef Medline

Xi G, Wai C, DeMambro V, Rosen CJ, Clemmons DR (2014) IGFBP-2 directly stimulates osteoblast differentiation. J Bone Miner Res 29:24272438. CrossRef Medline

Xie H, Xu J, Hsu JH, Nguyen M, Fujiwara Y, Peng C, Orkin SH (2014) Polycomb repressive complex 2 regulates normal hematopoietic stem cell function in a developmental-stage-specific manner. Cell Stem Cell 14:68 80. CrossRef Medline

Yamazaki T, Sabit H, Oya T, Ishii Y, Hamashima T, Tokunaga A, Ishizawa S, Jie S, Kurashige Y, Matsushima T, Furuta I, Noguchi M, Sasahara M (2009) Activation of MAP kinases, Akt and PDGF receptors in injured peripheral nerves. J Peripher Nerv Syst 14:165-176. CrossRef Medline

Zhao XD, Han X, Chew JL, Liu J, Chiu KP, Choo A, Orlov YL, Sung WK, Shahab A, Kuznetsov VA, Bourque G, Oh S, Ruan Y, Ng HH, Wei CL (2007) Whole-genome mapping of histone H3 Lys4 and 27 trimethylations reveals distinct genomic compartments in human embryonic stem cells. Cell Stem Cell 1:286-298. CrossRef Medline

Zheng H, Chang L, Patel N, Yang J, Lowe L, Burns DK, Zhu Y (2008) Induction of abnormal proliferation by nonmyelinating Schwann cells triggers neurofibroma formation. Cancer Cell 13:117-128. CrossRef Medline

Zhu Y, Ghosh P, Charnay P, Burns DK, Parada LF (2002) Neurofibromas in NF1: Schwann cell origin and role of tumor environment. Science 296: 920-922. CrossRef Medline 